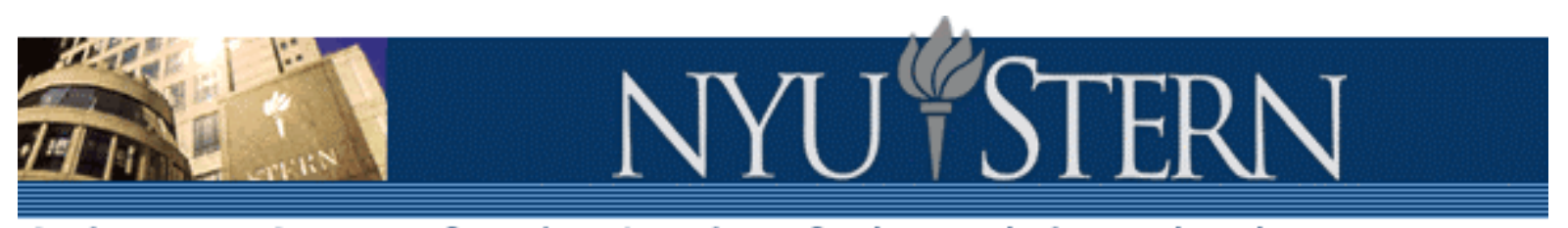

Salomon Center for the Study of Financial Institutions Working Paper Series ASSET MANAGEMENT Research Group

THE INVESTMENT BEHAVIOR OF PRIVATE EQUITY FUND MANAGERS

Alexander Ljungqvist

Matthew Richardson

SC-AM-03-12 


\section{The Investment Behavior of Private Equity Fund Managers * $*$}

\author{
Alexander Ljungqvist \\ Stern School of Business \\ New York University \\ and $C E P R$
}

\author{
Matthew Richardson \\ Stern School of Business \\ New York University \\ and NBER
}

October 30, 2003

\footnotetext{
* We are grateful to an anonymous institutional investor for making the data used in this study available, to the Salomon Center at NYU Stern for generous financial assistance, and to Eric Green for many helpful discussions and suggestions. We also thank Colin Blaydon, Wayne Ferson, Steve Kaplan, Holger Mueller, Maureen O'Hara, Marco Pagano, Antoinette Schoar, Robert Whitelaw, Jeff Wurgler, participants at the 2003 Western Finance Association meeting, the 2003 Stanford GSB/NYSE Conference, the $1^{\text {st }}$ RICAFE Conference at the London School of Economics, the NYU Monday Seminar, and numerous members of the private equity community for many helpful comments. We are grateful to Eric Stern for excellent research assistance. All errors are our own.

${ }^{\dagger}$ Address for correspondence: Salomon Center, Stern School of Business, New York University, Suite 9-160, 44 West Fourth Street, New York NY 10012-1126. Fax 212-995-4220. e-mail aljungqv@ @stern.nyu.edu (A. Ljungqvist), mrichar0@stern.nyu.edu (M. Richardson).
} 


\title{
The Investment Behavior of Private Equity Fund Managers
}

\begin{abstract}
Using a unique dataset of private equity funds over the last two decades, this paper analyzes the investment behavior of private equity fund managers. Based on recent theoretical advances, we link the timing of funds' investment and exit decisions, and the subsequent returns they earn on their portfolio companies, to changes in the demand for private equity in a setting where the supply of capital is 'sticky' in the short run. We show that existing funds accelerate their investment flows and earn higher returns when investment opportunities improve and the demand for capital increases. Increases in supply lead to tougher competition for deal flow, and private equity fund managers respond by cutting their investment spending. These findings provide complementary evidence to recent papers documenting the determinants of fund-level performance in private equity.
\end{abstract}

JEL Classification: G23, G11.

Key words: Private equity; Venture capital; Alternative investments; Fund management. 


\section{Introduction}

The goal of this paper is to try and better understand how private equity funds ('PEF's) make investment decisions in a competitive market. How competition affects the private equity sector is an interesting question because it involves the interaction of three distinct economic agents - investors, financial intermediaries (i.e., PEFs) and entrepreneurs. Our paper complements a recent literature that looks at this question theoretically, most notably Inderst and Mueller (2003). With specific reference to PEFs, Inderst and Mueller show how changes in demand and supply affect (i) the valuation and success of PEFs' investments, and (ii) the search time and screening by PEFs with respect to their investments. In this paper, we investigate some of these issues empirically by documenting the microeconomics of the investment behavior of private equity fund managers when faced with different economic environments.

Specifically, we analyze the role of competition among PEFs and the stickiness with which the PEF market adjusts to demand shocks in the context of four questions: What determines (i) the speed with which PEFs invest their capital over time, (ii) how long it takes them to return capital to their investors, (iii) when they exit their portfolio investments, and (iv) what returns they earn on their portfolio companies? For this, we make use of a unique and proprietary dataset made available to us by one of the largest institutional investors in private equity. Our dataset includes, among other items, precisely dated cash flows representing investments in 3,800 portfolio companies by several hundred private equity funds. The dataset accounts for approximately $20 \%$ of all capital raised by PEFs over the period 1981 to 2001 and so affords a comprehensive view of investment behavior in the private equity fund industry.

Our dataset has two important advantages over others used in the literature. First, because we know the exact timing of the cash flows (and thus the timing of both the investment and exit decision), we are able to relate PEF managers' decisions to measures of market competition and investment opportunities that are distinct from each other. Employing these measures, we find evidence consistent with the importance of changes in the demand for private equity capital and stickiness in its supply for explaining the observed behavior of PEF managers. For example, we show that time variation in the availability of investment opportunities and competition for deal flow with other private equity funds significantly affect the time a fund takes to invest its committed capital and then return it to its investors.

The second advantage is that we are able to document not only aggregate PEF behavior at the fund level, but also the individual investment decisions within a PEF's portfolio. Therefore, we are able to 
analyze the determinants of how long it takes PEFs to exit their investments, that is, the length of the 'holding period' for each portfolio company. Similarly, we analyze the returns that PEFs earn on each of their portfolio holdings. We show that holding periods are shorter and the corresponding success rates are higher following improvements in the availability of investment opportunities. Analogously, investments are held for longer, and are less successful, when competition for deal flow is tougher. We argue that this is consistent with an underlying model for imperfect competition among PEFs, and that it relates closely to implications from Inderst and Mueller (2003).

Our paper adds to several well-documented empirical facts from an emerging literature on private equity that begins to piece together the interaction of PEFs with the rest of the economy. First, Gompers and Lerner (1998) document that aggregate flows into the private equity sector tend to be driven by demand shocks. Second, Gompers and Lerner (2000) and Kaplan and Stein (1993) argue and document that too much capital can flow into the PEF sector, leading to a 'money chasing deals' phenomenon. Third, Kaplan and Schoar (2003) document that better performing funds have an easier time raising capital for follow-on funds and that follow-on funds perform better than the overall pool of funds. We argue that our findings are consistent with these facts in the context of a model for imperfect competition among PEFs.

We organize the paper as follows. In Section 2, we describe a framework for understanding competition in the PEF sector and discuss several empirical implications. Because the dataset is new, Section 3 describes in detail its various properties. Of some interest, we provide a comparison of our sample of PEFs to the larger (albeit much less detailed) Venture Economics dataset used by other authors. Sections 4 and 5 provide the core results of the paper by documenting the investment patterns of private equity funds over the last 20 years. In Section 4, we investigate the key determinants of the investment and exit decisions of PEFs at the fund level. Section 5 provides results on PEFs' exit strategies at the individual investment level and documents their 'hit' rates with a corresponding analysis of the determinants of investment-level returns. Section 6 suggests a potential important area of future research that ties into ours and existing results in the PEF literature.

\section{Framework: The Competitive Market for PEFs}

Consider the market for private equity. PEFs raise money from institutional and other investors and channel it to entrepreneurs. PEFs are typically structured as limited partnerships with a fixed (usually ten-year) life and thus resemble closed-end funds. The so called general partners or GPs managing the fund receive an annual fee of around 1-2\% of capital under management and take a slice of the fund's profits (the carried interest or carry), typically 20\%. Investors (the limited partners or LPs) commit 
capital to the fund which GPs draw down over the fund's life whenever they wish to invest in a portfolio company.

We assume that the institutions and individuals who wish to invest in private equity funds supply their capital competitively. Thus, if this asset market is rational, investors will provide capital to PEFs until their risk-adjusted expected returns (net of fees) equal the expected returns they could earn elsewhere. The PEFs in turn invest in entrepreneurial projects. Positive net present value projects correspond to business plans that produce competitive advantage. Though entrepreneurs eventually face competition in the product market, they are at least initially monopolists with respect to their business plans.

In this setting, what type of investment behavior and returns do we expect to observe among private equity funds? This depends on how competitively PEFs supply their capital to entrepreneurs. Assume first that there is perfect, frictionless competition among the PEF managers who wish to invest in particular entrepreneurial projects, and suppose a technological shock hits the entrepreneurial market. This shock could be the development of the personal computer, changes in the way the FDA approves drugs, the development of the internet, the creation of the high-yield debt market, and so forth. Conditional on the shock, entrepreneurs demand capital from the market. The literature argues that private equity funds are the cheapest source of financing when private firms are subject to extreme informational asymmetries and high degrees of uncertainty (e.g., Gompers and Lerner (1999b)). In a perfect world, capital would flow immediately into PEFs which in turn would provide capital to the entrepreneurs. This story of supply responding to changes in demand is consistent with Gompers and Lerner (1998) who argue that most flows into and out of PEFs are driven by demand shocks.

To the extent that there are net present value gains, the excess returns would likely accrue to the entrepreneur. This follows from the assumption that investors will supply capital to PEFs until their risk-adjusted expected returns equal the opportunity cost of capital. Presumably, the services PEFs provide to entrepreneurs are fully compensated for by the stakes they take in the ventures, which in turn are offset by the fees paid to the PEFs by the investors. ${ }^{1}$ (See, for example, Gorman and Sahlman (1989), Palepu (1990), Gompers and Lerner (1999b), and Hellmann and Puri (2002) for the types of specialized services that PEFs provide to entrepreneurs.) Thus, investors and PEF managers would break even in expectation, and no firm predictions about investment behavior can be made.

\footnotetext{
${ }^{1}$ Jones and Rhodes-Kropf (2003) argue that, due to the principal-agent problems associated with private equity investing, PEFs necessarily hold undiversified positions. Thus, part of the compensation to PEFs relates to the level of idiosyncratic risk faced by fund managers.
} 
There are strong reasons, however, to question this idealized view of the PEF market. In the Inderst and Mueller (2003) model, the entrepreneur's bargaining power relative to the venture capitalist varies with changes in the demand and supply of capital. If the supply of PEFs in the short run is somewhat fixed, then a sudden shift in the demand for entrepreneurial capital will lead to a transfer of rents from the entrepreneur to existing PEFs (and their investors ${ }^{2}$ ) until the supply of PEFs catches up (see also Sahlman (1990)).

The stickiness of the PEF market is not without justification. First, relative to other asset classes, it is well known that private equity investments are illiquid. That is, there is no active secondary market for such investments, investors have little control over how their capital is invested, and the investment profile covers a long horizon. If the supply of available capital that puts zero price on liquidity is limited, then this will lead to rent transfers from the entrepreneur. ${ }^{3}$ Second, once a fund has been raised, its size cannot subsequently be increased (though in recent years some funds have cut their size). Thus, reacting to an increase in demand requires raising a new fund which at minimum takes several months. Third, and perhaps more important, it is often argued that PEF managers possess unique skills that are not easily duplicated overnight. This limits established GPs' ability to raise additional funds (to avoid overstretch) and constrains to some extent entry by new fund managers. The skills in question include the ability to screen investment proposals and monitor entrepreneurs (both indirectly and directly through sitting on companies' boards), a 'rolodex' of contacts who can help add value to the ventures, and access to financing (e.g., Gompers (1995), Gompers and Lerner (1996), Lerner (1994), and Hellmann and Puri (2002)). The contacts in particular are built up through years of experience and working in the industry.

Some argue that there is an additional imperfection in the PEF market. At times, too much capital flows into the PEF sector, so that capital investment can actually overshoot, leading to the 'money chasing deals' phenomenon documented by Gompers and Lerner (2000) and Kaplan and Stein (1993), and studied in a specific example by Sahlman and Stevenson (1986). This apparent breakdown of efficiency on the investor side is usually considered behavioral (see, for example, the herding literature and, in particular, Wermers (1999) for his application to mutual funds). However, it could simply

\footnotetext{
${ }^{2}$ Who ultimately earns the excess rents would depend on the contractual arrangements between the PEF and the investors. To the extent that there is little variation across contracts, investors earn some of the excess returns. Excess returns may be offset by poor returns if the investor mis-times the cycle (see below). Alternatively, it has been argued that there exist subtle, yet important, differences across PEF contracts (e.g., Gompers and Lerner (1999a)).

${ }^{3}$ Recent work by Lerner and Schoar (2003) argues that incentive problems between PEFs and investors can be alleviated by the PEF using illiquidity to screen for investors who are less subject to liquidity shocks. For our example, the PEFs would need to trade off the benefits of having liquid investors versus the shortage of such investors.
} 
reflect investors trying to take advantage of the stickiness of the PEF market, which makes excess returns possible. If the technological shock is unpredictable, then the returns earned in 'sticky' markets and in 'money chasing deals' markets may average out to be normal rates of return. This is an important area of research which we discuss in greater detail in the paper's conclusion.

Of course, these two views of the PEF market are entirely mutually consistent. A technological shock hits the entrepreneurial market, leading to an initial shortage of PEF-based capital and high returns, only to be supplemented (perhaps overly so) with new PEF capital once the market adjusts. Note that this is also a direct result of equilibrium in the Inderst and Mueller (2003) model.

This framework has implications both for how investment decisions are made and for their relative success. Consider a fund manager's investment behavior following a technological shock, in a world where the supply of private equity capital is sticky in the short run. Ceteris paribus, the manager of a fund that is already in place should invest his capital as fast as possible in promising projects, before new PEFs are created to invest in the same opportunities. Thus a PEF's investment rate should increase as more promising investment opportunities arise. These investments should also yield higher returns. On the other hand, holding the number of projects fixed, an increase in competition for deal flow among the PEFs makes it harder for the fund manager to find the so-called 'diamonds in the rough', leading to a slow-down in the investment rate. This effect corresponds to Inderst and Mueller's (2003) prediction that the PEF manager's search time increases when competition intensifies. Greater competition presumably also implies that the fund manager will find it more difficult to extract rents from the entrepreneur. A manager trying to maximize the returns on the fund's investments will then take longer to invest the fund's capital to avoid overpaying. ${ }^{4}$

In terms of capital return and exit decisions, we expect that funds that faced tough competition when making their investments will take longer to return capital to their investors and exit their portfolio holdings later. In part this follows because, as mentioned above, funds take longer to invest when competition is tough. Moreover, we expect funds facing tough competition to make more marginal investments which need more 'nursing' before they can be exited, and which arguably have higher mortality rates (see Bengtsson, Kaplan, Martel, and Strömberg (2002) for evidence that VCs screen less when competition for deal flow is intense). Improvements in the investment environment (say in response to technological shocks), on the other hand, should serve to accelerate both capital

\footnotetext{
${ }^{4}$ Alternatively, one might model the effects of changes in demand when supply is fixed in the short run using a twoequation demand/supply model. However, like other researchers, we lack data on the prices (valuations) paid for private equity stakes and so cannot identify such a system. Fortunately, our results are consistent with the demand/supply predictions outlined in this Section.
} 
returns at the fund level and exits at the investment level.

A corollary of this analysis is that PEFs that can react quickly to market conditions, say by being able to raise funds on short notice, would have a comparative advantage. Along these lines, Kaplan and Schoar (2003) find that better performing funds have an easier time raising capital for follow-on funds. Interestingly, their comprehensive analysis of the performance of 746 PEFs raised between 1980 and 1995 shows that (i) follow-on funds perform better than the overall pool of funds, and (ii) funds raised in boom times (i.e., with considerable PEF competition) tend to perform worse. These results are consistent with the notion of a competitive advantage and show support for the model of the private equity market described above. We will return to the implications of our analysis for who earns excess returns in the private equity market in the concluding section.

\section{Sample and Data}

\subsection{Overview of Dataset}

Our dataset is derived from the records of one of the largest institutional investors in private equity in the U.S. We will refer to this investor as the 'Limited Partner'. As a condition for obtaining the data, we have agreed to identify neither the Limited Partner nor the names of the funds or portfolio companies in the dataset. The Limited Partner began investing in private equity in 1981, in the wake of the institutionalization of the private equity industry following the 1980 ERISA 'Safe Harbor' regulation, and has since invested in hundreds of funds, all of which are included in our analysis. ${ }^{5}$ The funds, in turn, have invested in 3,800 portfolio companies. The number of funds the Limited Partner participated in increased throughout the 1990s, peaking in 1999-2000, similar to the pattern documented for PEFs in general by Venture Economics (VE), a commercial data vendor.

Table 1 presents descriptive statistics for our sample. To protect the Limited Partner's identity, we have agreed not to disclose in this table certain characteristics of funds raised after 1993, such as their number and average size, as these are still active investments. (However, we include the underlying cash flow data for all funds in our subsequent analyses.) The table thus contains more complete information for the 73 private equity funds the Limited Partner invested in between 1981 and 1993. We define these funds as 'mature' funds since they are around ten or more years old and have completed their investment activity and capital distributions.

\footnotetext{
${ }^{5}$ The institutionalization of the private equity industry is commonly dated to three events: the 1978 Employee Retirement Income Security Act (ERISA) whose 'Prudent Man' rule allowed pension funds to invest in higher-risk asset classes; the 1980 Small Business Investment Act which redefined PEF managers as business development companies rather than investment advisers, so lowering their regulatory burdens; and the 1980 ERISA 'Safe Harbor' regulation which sanctioned limited partnerships which are now the dominant organizational form in the industry.
} 
Our dataset contains both venture capital and buyout funds. ${ }^{6}$ For the entire period from 1981 to 2001, a quarter of funds, representing $14.8 \%$ of fund capital, are venture funds. This differs from the more comprehensive sample of funds tracked by VE, where venture funds account for $41.5 \%$ by capital. Our Limited Partner thus invests disproportionately in buyout funds.

In the private equity industry, fund size is usually expressed as the sum of investors' 'capital commitments'. The capital commitment is the maximum amount of money an investor can be asked to contribute over the life of the fund. Between 1981 and 2001, sample funds had aggregate commitments of $\$ 207$ billion (in nominal terms). Mature funds had aggregate commitments of $\$ 36.7$ billion, with the average fund raising \$502.8 million. Buyout funds were substantially larger than venture funds, averaging capital commitments of $\$ 599.7$ million versus $\$ 227.5$ million. Compared to the sample of funds tracked by VE, our funds are large: Kaplan and Schoar (2003) report average fund sizes for buyout and venture funds of \$262 million and \$53 million between 1980 and 1995, respectively.

Our Limited Partner's investment in the private equity industry is sizeable. Between 1981 and 2001 , it committed $\$ 5.5$ billion to PEFs, with the median fund receiving $\$ 10$ million. As a fraction of total fund size, the Limited Partner committed $4.7 \%$ of the average fund's capital, making it one of the larger investors.

\subsection{Sample Selection}

Apart from being skewed toward larger and buyout funds, how representative is our funds sample? First, note that our data are not subject to survivorship bias as all investments the Limited Partner has made since 1981 are included. Second, our sample covers a large fraction of the PEF 'universe'. The $\$ 207$ billion raised in aggregate by our funds represent $17.5 \%$ of the $\$ 1.184$ trillion in aggregate commitments in the broader VE sample over the 1981-2001 period (see Table 1). Our coverage is even better among buyout funds, accounting for $29.3 \%$ of capital committed to those funds. Thus, our sample represents a reasonable cross-section of large buyout funds and a smaller cross-section of large venture funds. By implication, our results may not be representative of the investment behavior of smaller funds.

Third, the extent to which the funds in our dataset are representative of the universe of private equity funds depends in part on the Limited Partner's investment strategy. For instance, it would be problematic if the Limited Partner only invested in follow-on funds raised by managers with proven

\footnotetext{
${ }^{6}$ Venture funds are those identified as 'Venture Capital' by Venture Economics. Most non-venture funds are flagged as 'Buyout' (90.4\%); the remainder are flagged as 'Generalist Private Equity' (3.8\%), 'Mezzanine' (4.8\%), and 'Other Private Equity' (1\%). We will refer to these funds collectively as buyout funds.
} 
track records, in the manner of a fund-picking 'fund-of-funds' operation. This is not the case. Table 1 shows that in our dataset, $27.7 \%$ of funds raised between 1981 and 2001 are first-time funds, $21 \%$ are second funds, $11.6 \%$ are third funds, and the remaining $39.7 \%$ are later funds. Among mature funds raised before 1994, as many as $34.8 \%$ are first-time funds, a rate that is not much lower than the $40 \%$ reported by Kaplan and Schoar (2003) for the VE database.

In part, the relatively high incidence of first-time funds follows from the Limited Partner's twin investment objectives: not only to obtain the highest risk-adjusted return, but also to increase the likelihood that the funds will 'purchase' the services our Limited Partner's corporate parent has to offer. Economies of scale in the provision of these services explain our Limited Partner's tendency to invest in larger than average funds. These services are arguably more attractive to first-time funds that have yet to build up relationships.

Fourth, as in all studies with limited samples, the question of selection bias arises. There are two possibilities here. The first is that the Limited Partner picked PEFs which were ex post unusual in how they invested and distributed capital. For example, with respect to capital returns, perhaps the Limited Partner chose more liquid investments (i.e., PEFs that paid off more quickly) or had extraordinary fund-picking ability in choosing PEFs that ended up with many more 'hits'. We tend to discount this possibility. As described above, the Limited Partner's primary motivation for investing in these funds was to build relationships for the benefit of its corporate parent. Moreover, we know that the Limited Partner is not organized as a professional fund-picking ('fund-of-funds') operation. Finally, members of the private equity community who have seen our results tell us they look representative.

The second possibility is that the Limited Partner might be exceptional in that it 'survived' these past 20 years, so that we observe its data more by virtue of its luck in investing in winner funds than because private equity funds were good investments on average. While this point is probably not particularly relevant (investing in private equity accounts only for a small part of the Limited Partner's overall business), we can shed more light on it directly by comparing the performance of our funds to the performance of the wider VE sample. ${ }^{7}$ Kaplan and Schoar (2003) report that cash flow IRRs averaged 18\% among the 746 mature funds raised in 1980-1995 that are covered by VE. In our sample of 73 mature (albeit larger) funds, IRRs average 18.13\%, which is unlikely to be significantly different.

\subsection{Cash Flows}

The Limited Partner made available to us the complete cash flow records for all its private equity

\footnotetext{
${ }^{7}$ We thank Steve Kaplan for this suggestion.
} 
investments up to May 31, 2001. We subsequently obtained additional data up to September 30, 2002 for 21 funds that were close to maturity, thus increasing the number of funds that have been liquidated or are close to liquidation. A typical record consists of the date and amount of the cash flow, the fund and portfolio company to which it relates, and the type of transaction. Transaction types include 'disbursements' (investments in portfolio companies) and 'exits' (receipt of cash inflows from IPOs or trade sales); dividends or interest paid by portfolio companies; annual management fees (typically 1$2 \%$ of committed capital); and (occasional) interest payments on cash held by GPs prior to making an investment. The data do not separately record the GPs' share in a fund's capital gains (usually 20\%), as GPs transmit capital gains to investors net of their 'carried interest'.

The cash flows involve four types of investment scenarios. 1) Cancelled transactions: a cash call followed shortly after by the return of the cash, along with bank interest. 2) Write-offs: cash outflow(s) without subsequent cash inflow, or with a subsequent accounting (non-cash) entry flagging a 'capital loss'. 3) Cash distributions following successful exits (in the form of an IPO or a trade sale): cash outflow(s) followed by cash inflow(s). And 4), stock distributions following successful exits: cash outflow(s) followed by a non-cash entry reflecting receipt of common stock. The stock would be the portfolio company's in the case of an IPO, and the buyer's in the case of a sale to a publicly traded firm. Following a stock distribution, one of two things can happen: the Limited Partner sells the stock, or it holds it in inventory. Sales show up as cash inflows. Positions that are held in inventory are marked to market periodically (usually monthly), but they are obviously not cash. Upon receipt of distributed stock, our Limited Partner virtually always liquidates the distributed stock.

\subsection{Portfolio Compositions and Industry Specializations}

Venture Economics assigns companies to six broad industry groups: 'Biotechnology', 'Communications and Media', 'Computer Related', 'Medical/Health/Life Science', 'Semiconductors/Other Electronics', and 'Non-High-Technology'. Companies that do not appear in VE are assigned manually to these industry groups, using Dun \& Bradstreet's Million Dollar Database, SIC codes that are available from standard sources for companies that have gone public, verbal information contained in fund reports received by our Limited Partner, and news and web searches. 209 companies that cannot be assigned unambiguously to one of the six VE groups are assigned to a new 'Miscellaneous' group.

Of the 3,800 companies that our sample funds invested in between 1981 and 2001, 3\% are assigned to 'Biotechnology', 17\% to 'Communications and Media', 18\% to 'Computer Related', $7 \%$ to 'Medical/Health/Life Science', 4\% to 'Semiconductors/Other Electronics', 45\% to 'Non-High- 
Technology', and 6\% to 'Miscellaneous'. The high proportion of non-high-technology portfolio companies reflects the large number of buyout funds in the sample.

Funds rarely invest in only one industry. We take a sample fund's industry specialization to be the broad VE industry group that accounts for most of its invested capital. On this basis, $14 \%$ of funds specialize in 'Communications and Media', 11\% in 'Computer Related' companies, 4\% in 'Medical/Health/Life Science', 3\% in 'Semiconductors/Other Electronics', and 59\% in 'Non-HighTechnology'. Our sample contains no funds specializing in 'Biotechnology'.

\section{The Investment and Capital Return Decisions of Private Equity Funds}

There is a large empirical literature on the investment process of private equity funds. However, this literature almost exclusively analyzes the contractual relations between PEFs and the firms in their portfolios. (See Gompers (1995), Lerner (1994), Kaplan and Strömberg (2003), and Hellmann and Puri (2002), among others.) In this section, we take contracts as given and instead empirically analyze how a private equity fund invests its capital over its life in the context of the descriptive model of the PEF market outlined in Section 2. When a PEF receives a capital commitment from investors, the capital is not put to use immediately and instead is drawn down only when the PEF is ready to invest in a portfolio company. We document the dynamics of these draw downs over a fund's life, as well as how quickly capital gets returned. Of particular importance, we show that there is substantial crosssectional variation in draw down rates and capital return rates, and we perform a duration analysis of the determinants of how fast or how slowly these flows occur. However, we first document some new stylized facts that serve as a backdrop for our analysis.

\subsection{Cash Flow Patterns: Draw Downs and Capital Distributions}

Table 2A shows how much of the committed capital was drawn down by the earlier of the end of our sampling period or a fund's liquidation date. The average fund in our sample has drawn down $67.3 \%$ of committed capital. However, this understates draw downs as the more recent funds are not yet fully invested. The 73 funds raised between 1981 and 1993 invested on average $94.8 \%$ of committed capital. Average draw downs are around $90 \%$ of committed capital for funds raised up to 1996, with later vintages still actively investing and so still in what is called the 'commitment period'.

It is arguable when a fund is fully invested. Among the funds raised between 1981 and 1993 that have subsequently been liquidated, some never invested more than 60 to $70 \%$ of committed capital. In the overall 1981-2001 dataset, 55.6\% of funds have invested at least $70 \%$ of committed capital, and $49.5 \%$ have invested $80 \%$ or more as of the end of our sampling period. These might reasonably be thought of as fully, or close to fully, invested. They include a few recent funds that invested their 
committed capital very rapidly: $40 \%$ of the 1998 vintage funds and $10 \%$ of the 1999 vintage funds had already invested at least $70 \%$ of committed capital by May 2001.

As mentioned earlier, PEFs rarely draw down their committed capital at the outset, issuing capital calls instead when investment opportunities present themselves. Figure 1 sheds light on the time profile of draw downs for the average sample fund. The figure shows average cumulative draw downs for each year of a fund's life (counted from 1 to 10), divided by committed capital. The average fund draws down $16.28 \%, 20.35 \%$, and $20.15 \%$ of committed capital in its first three years of operation, so it is $56.8 \%$ invested by the end of year 3 . The draw down rate then slows down. In fact, it takes another three years to hit a $90 \%$ rate. By year 10 , the end of its expected life, the average fund is $93.6 \%$ invested. (While some funds remain in operation beyond year 10, there are no further draw downs.)

Though not shown in the figure, there is wide variation in the speed with which funds draw down committed capital. For instance, some funds draw it down in year 1, while others take as long as ten years to invest $80 \%$ or more of their commitments. Adjusting for the fact that many of the more recent funds are right-censored, in that they drop out of our sample before they are fully invested, the average (median) fund takes 11.7 (11) quarters to invest $80 \%$ or more of its commitments.

On the flip side of the draw down decision, following liquidity events (such as an IPO), capital is returned to investors in the form of cash distributions or stock distributions. (Private equity funds typically have covenants restricting reinvestment of capital gains; see Gompers and Lerner (1996).) Table 2B shows how much of the invested and committed capital was returned to investors by the earlier of the end of our sampling period or a fund's liquidation date. The average fund distributed $106.8 \%$ of drawn-down capital and $94.3 \%$ of committed capital. Again, this understates cash flows as recent funds have yet to exit many of their portfolio holdings. The 73 funds raised between 1981 and 1993 returned 2.59 times invested capital and 2.45 times committed capital, on average.

Figure 1 documents the rate at which capital returns and capital gains are distributed to investors over the life of the average fund. As one might expect, distributions are rare in the early fund years. For example, by the end of year 3, only $12.9 \%$ of total committed capital has been distributed on average. Note that it takes around seven years for committed capital to be returned, so much of the 'capital gain' is generated from year 7 onwards. By year 10, the average fund has distributed 1.93 times its committed capital. Some funds have further distributions beyond year 10, which are not illustrated in the figure.

These results have important implications for measuring performance and the liquidity of investing in a PEF. Specifically, draw downs (cash outflows) and distributions (cash inflows) are the raw inputs 
when assessing fund performance, but there is another ingredient: the time profile of cash flows. The later the cash outflows, and the sooner the cash inflows, the better is a fund's performance. Figure 1 shows that these cash flows occur throughout the life of the fund and thus must be taken into account at the time they occur when calculating a fund's return. This is a useful stylized fact therefore that should be incorporated by the literature on PEF performance.

\subsection{The Determinants of Draw Downs}

To shed light on the determinants of how quickly a fund invests its capital, we model the time-tofully-invested as $\ln \left(t_{\mathrm{i}}\right)=\beta \mathbf{X}+\ln \left(\varepsilon_{\mathrm{i}}\right)$, where the error $\varepsilon_{\mathrm{i}}$ is assumed to follow the exponential distribution with mean $\beta_{0}$, the constant. This is a standard accelerated-time-to-failure model, which is perhaps more familiar when rewritten as a proportional-hazard duration model. One advantage of failure models is that the likelihood function has no problem correcting for the right-censoring inherent in the data (Kalbfleisch and Prentice (1980)). ${ }^{8}$ Thus, we estimate the model using all sample funds raised between 1981 and 2001, including those that drop out of the sample before becoming fully invested. (Our results are qualitatively unaffected if we restrict the sample to the mature funds raised between 1981 and 1993, which are not subject to right-censoring.)

The model outlined in Section 2 suggests that time-to-fully-invested varies with the (time-varying) availability of investment opportunities and competition for such investment opportunities, such that funds invest their capital more rapidly when technological and other shocks increase the availability of promising ventures and when they face less competition for deal flow. We also allow for potential differences between venture and buyout funds, first-time and follow-on funds, and by fund size, and control for changes in the cost of capital.

As our proxy for the unobserved availability of investment opportunities faced by a buyout (venture) fund in our sample, we use the quarterly log number of companies in a buyout (venture) fund's industry of specialization that receive buyout (venture) funding according to Venture Economics. Funds' industry specializations are as defined in Section 3.4. For instance, an increase in the number of 'Biotechnology' companies being funded is assumed to signal an improvement in biotech investment opportunities. This variable is time-varying: when investment opportunities (as proxied by our variable) change over the life of a sample fund, the fund's managers can respond by accelerating or decelerating the rate at which they invest. Given the framework outlined in Section 2,

\footnotetext{
${ }^{8}$ In the absence of censoring, the likelihood of the data is simply the product of the conditional densities $f\left(t_{\mathrm{i}} \mid \beta, \mathrm{x}_{\mathrm{i}}\right)$ for all observations $i$. For a censored observation, the time at which 'failure' occurs is unknown, as failure occurs after the end of the observation period, $T$. All that is known is that failure hasn't yet occurred as of time $T$. The appropriate contribution to the likelihood function of a censored observation is therefore the probability of not having failed prior to $T$.
} 
the time-varying nature of our proxy for investment opportunities is crucial, as we are interested in how investment behavior responds to changes in the demand for private equity when the supply of private equity is sticky in the short run.

We augment this proxy for investment opportunities with a 'bubble dummy' that equals one during the heyday of the new-economy boom (1999Q1-2000Q2), on the assumption that investment opportunities were more abundant in those years. This too is a time-varying covariate: over the fund's life, it equals one only in 1999Q1-2000Q2. ${ }^{9}$

To proxy for the degree of competition faced by a buyout (venture) fund in our sample, we construct three variables. The first measures how much financial 'fire power' the fund's most direct competitors have access to, and is defined as the amount of capital committed to buyout (venture) funds in the year the sample buyout (venture) fund was raised, in log dollars of 1996 purchasing power. This definition assumes that (say) a 1990 vintage fund competes primarily with other funds of that vintage. (Our results are qualitatively unchanged if we widen the window to include capital committed in the year before and after the fund's vintage year.) Note that this variable is not timevarying and is similar to the proxy used by Gompers and Lerner (2000).

Our second variable, 'aggregate per-industry disbursements', attempts to provide a proxy for competition for individual deals. It is defined as the real aggregate amount of capital invested by all Venture Economics funds in companies that fall within the sample fund's industry specialization. For instance, a buyout fund specializing in cable company acquisitions (VE group 'Communications and Media') is treated as facing competition for deal flow from other funds investing in 'Communications and Media' companies. We measure aggregate per-industry disbursements during a fund's first three years, as Figure 1 shows that this is when funds invest most actively. We expect that funds take longer to invest their capital, the more other funds invest in their industry of interest. Note the difference between this and our first proxy for competition: while the first proxy is a measure of the fire power available to a fund's competitors, the second is a measure of how much capital competitors are actually investing in the fund's industry of interest.

The third measure of competition seeks to control for the fact that the private equity market clearly grew and developed over the past two decades, becoming more competitive in the sense of greater market acceptance of the PEF business model and thus, presumably, lower barriers to entry for new funds. This suggests a time trend in the degree of competition existing managers face, with funds

\footnotetext{
${ }^{9}$ Gompers and Lerner (2000) use price/earnings and market/book ratios of public firms in CRSP and Compustat to control for industry-specific investment opportunities among private firms, but find neither to be statistically significant.
} 
raised earlier facing less competition than those raised in later years. To capture this, we include a trend variable that equals the inverse of the square root of the fund's vintage year, scaled such that 1981 equals 1 and later years have lower values. Given this definition, we expect a negative coefficient for the trend variable.

We include a number of controls for fund characteristics, specifically the size of the fund (in $\log$ real dollars), the type of fund (buyout versus venture), and the fund sequence number (first-time versus follow-on). We also control for changes in the cost of capital, using two measures: the yield on corporate bonds (using Moody's BAA bond index estimated quarterly in March, June, September, and December), and the quarterly return on the Nasdaq Composite Index. Both are time-varying over the life of a sample fund.

Table 3 reports the maximum-likelihood estimation results for three different cut-offs of 'fullyinvested' (more than $70 \%, 80 \%$, or $90 \%$ of committed capital). ${ }^{10}$ The results are qualitatively similar in each case. The table also reports models estimated separately for buyout and venture funds using the $80 \%$ cut-off. (Qualitatively similar results, not shown, obtain for the $70 \%$ and $90 \%$ cut-offs). The model $\chi^{2}$ statistics are large and highly significant in the three pooled models as well as in the buyoutonly and venture-only specifications, indicating good overall fit. The pseudo $R^{2}$ suggest that our models capture around a quarter of the variation in draw down rates.

We first discuss the three models that pool buyout and venture funds. Our proxy for the availability of investment opportunities behaves as predicted. The time-varying log number of firms receiving financing in a fund's industry of specialization has a negative and generally significant coefficient, suggesting that funds accelerate their draw-downs when investment opportunities in their chosen industry improve. This is consistent with the microeconomic analysis of Section 2 . The negative coefficient estimated for the dummy for the 'bubble' years 1999-2000 tells a similar story: funds were invested significantly faster in those two years, consistent with our conjecture that investment opportunities were more plentiful in 1999 and 2000. To better understand the economic significance of these results, consider a one-standard deviation decrease in the number of companies receiving financing in the fund's industry of specialization. The effect on the draw down schedule of the average fund is to lengthen the time it takes to invest at least $80 \%$ of its capital from 11.7 quarters to 27.5 quarters, holding all other covariates at their sample means.

\footnotetext{
${ }^{10}$ As mentioned in the previous sub-section, a small number of the mature funds never invested more than $60-70 \%$ of their capital. For these, we measure time-to-fully invested as the number of quarters until they reached their maximum draw down.
} 
As conjectured, our first two proxies for competition for deal flow - the total capital raised by other PEFs in the fund's vintage year, and aggregate disbursements by other PEFs into the fund's main industry of interest - have positive and significant effects on the time-to-fully-invested. Thus funds take longer to invest when their peers have more money available and when more money is invested in their chosen industries. This corroborates Gompers and Lerner's (2000) hypothesis that the private equity market is prone to having 'too much money chase the same deals', and confirms the equilibrium implications of Inderst and Mueller (2003), in the sense that PEF managers become more cautious when competition for deal flow intensifies. The coefficient estimated for the variable capturing the time trend in the evolution of the private equity market is negative and significant, suggesting that funds raised earlier in the period, when the PEF market was less developed, were invested significantly faster. (Note that this finding is not driven by the fact that many newer funds drop out of our sample before becoming fully invested, as we have corrected for right-censoring.) To illustrate the economic significance of these effects, we consider one-standard deviation increases in the amount of competing PEF capital raised and disbursed (measured in log real dollars). All else equal, these increase the timeto-fully-invested from the average of 11.7 quarters to 24.7 and 17.7 quarters, respectively.

Among fund characteristics, we find that venture funds take significantly longer to invest than buyout funds. We find no evidence that fund sequence number or fund size affect the investment rate. Increases in the cost of capital, as measured by the corporate bond yield, serve to reduce draw-down rates, indicating that funds invest more slowly as debt becomes more expensive. The effect is fairly large economically: all else equal, a one-standard deviation increase in bond yields would increase time-to-fully-invested from 11.7 to 29.1 quarters. Conditions in the public equity markets, on the other hand, do not influence investment behavior, in view of the insignificant coefficient estimated for the return on the Nasdaq Composite Index. Of course, these conditions are above and beyond those already captured by our proxies for investment opportunities and competition in the PEF market.

When we estimate the model separately for buyout and venture funds, we find similar results with one exception: aggregate per-industry disbursement, our second proxy for competition for deal flow, only has a significant effect on the draw down behavior of buyout funds. Venture funds are relatively more sensitive to our first competition proxy, the amount of money available to funds raised in the same vintage year. Note that changes in bond yields affect the investment behavior of both VC and buyout funds. Conversations with the Limited Partner suggest this effect either captures the fact that many venture funds in the sample specialize in 'growth equity', which more likely involves debt financing, or 'style drift' blurring the distinction between venture and buyout funds in the sample. 
In conclusion, these duration models provide supporting evidence for our hypothesis that fund behavior regarding investment decisions is a function of shocks to the availability of investment opportunities, lags in the PEF market's ability to respond to such shocks, and changes in the degree of competition for deal flow.

\subsection{The Determinants of Capital Returns}

Barry, Muscarella, Peavy, and Vetsuypens (1990), Lerner (1994), Gompers (1996), Brav and Gompers (2003), Black and Gilson (1998) and others have studied how private equity funds exit their portfolio companies. A key finding from this literature is that PEFs act strategically in their exit decisions, especially with respect to current exit market conditions and their need to build reputations. Our model of the PEF market suggests that competition and investment opportunities may also affect exit decisions. In this section, we model how PEFs exit their investments when the PEF market adjusts to changes in investment opportunities with a lag and the degree of competition for deal flow varies over time. This analysis complements Gompers and Lerner's (2000) 'money chasing deals' analysis, which shows that current valuations of portfolio companies are high when there is significant competition for deals.

To shed light on the determinants of how quickly a fund returns capital to its investors, we model the log of time (in quarters) between a fund being created and it returning at least $\mathrm{M}$ times the committed capital to the limited partners, using again accelerated-time-to-failure models. ${ }^{11} \mathrm{We}$ experiment with different cut-offs for $\mathrm{M}$, and report estimation results for $\mathrm{M}=1 \mathrm{x}, 1.5 \mathrm{x}$, and 2x capital. Adjusting for the fact that many of the more recent funds are right-censored, in that they drop out of our sample before they have had a chance to return their committed capital, the average (median) fund has returned 1x capital after 18.8 (18) quarters, with correspondingly longer periods for the higher cutoff points.

What determines capital returns? Having invested their capital, we expect funds to exit their portfolio companies (and so return capital to their limited partners) more rapidly, the more publicmarket investors are willing to pay for them. Their willingness to pay should increase in the investment opportunities available to companies in an industry. Thus we expect faster capital returns, the better are investment opportunities. As in Section 4.2, we proxy for investment opportunities using the $\log$

\footnotetext{
${ }^{11}$ We model return of committed rather than invested capital because PEFs do not invest their committed capital instantly. To see the difference, consider the example of a fund that has drawn down $20 \%$ of commitments by year 2, distributes $25 \%$ of committed capital following an early 'home run' in year 2, but takes until year 5 to invest all its committed capital and until year 9 to return it to investors. Time-to-return of 'invested capital' would be two years, while time-to-return of committed capital would be nine years. The latter is more economically meaningful.
} 
number of companies receiving financing in the fund's chosen industry of specialization. We also include a dummy equaling 1 during the heyday of the new-economy boom (1999Q1-2000Q2), on the assumption that the exit market was particularly favorable in those two years.

Funds facing tougher competition for deal flow find it harder to invest - as shown in Section 4.2 which implies that they will also take longer to return capital to their investors. We use the three proxies for competition for deal flow introduced earlier: the total capital raised by other PEFs in the fund's vintage year (our measure of fire power), aggregate disbursements by other PEFs into the fund's main industry of interest (our measure of the amount of money chasing similar deals), and the time trend variable.

Finally, we control possible differences across funds by including variables identifying venture and first-time funds, respectively, and log fund size. We also control for the effects of variations over time in capital market and exit market conditions. We identify and investigate four possible factors: (i) the corporate bond yield as a measure of the cost of capital; (ii) the quarterly return on the Nasdaq Composite Index, intended to capture the well-documented link between IPO activity and market conditions (Loughran, Ritter, and Rydqvist (1994)); (iii) the quarterly number of private equity-backed IPOs in the same broad VE industry, as a signal of how 'hot' the IPO market is; and (iv) the quarterly number of private equity-backed M\&A deals in the same broad VE industry, as a signal of how 'hot' the M\&A market is. Cheap debt, well-performing stock markets, receptive IPO markets and active M\&A markets should favor faster return of committed capital.

Table 4 reports maximum-likelihood estimates for the pooled sample using the three cut-offs and separately for buyout and venture funds using the 1x cut-off (qualitatively similar results obtain for the $1.5 \mathrm{x}$ and $2 \mathrm{x}$ cut-offs). The model $\chi^{2}$ statistics are large and highly significant in all five models, indicating good overall fit. The pseudo $R^{2}$ suggest that our models capture around a half of the variation in capital return decisions.

As predicted, funds return capital significantly faster, the more companies receive financing in a fund's industry of interest. This is true for all cut-offs and for venture funds and buyout funds separately. Recall that we interpret an increase in the number of investments as an improvement in opportunities and valuations. For example, if the outlook for optical switches improves, we would expect more new ventures in the optical switches space to be funded, and at the same time existing funds with investments in such companies should find it easier to exit them. To illustrate the economic magnitude of the effect, a one-standard deviation increase in the log number of companies receiving financing in their chosen industry of specialization would cut the time to returning $1 \mathrm{x}$ the committed 
capital from the average of 18.8 to 4.2 quarters.

Competition for deal flow leads to slower capital returns, as conjectured. The effect is large economically: a one-standard-deviation increase in the variable measuring the amount of capital available to same-vintage year funds would delay the return of $1 \mathrm{x}$ committed capital by nearly two years, from 18.8 to 25.8 quarters. How much competing funds actually invested in a sample fund's chosen industry has a positive effect on time-to-returning capital, but this is significant only in the pooled $1 \mathrm{x}$ and venture-only specifications. The significantly negative coefficient estimated for the trend variable shows that funds raised earlier returned their capital more rapidly, consistent with the notion that earlier funds faced a less competitive PEF environment generally.

Fund characteristics are not generally significant, with one exception: venture funds are significantly faster than buyout funds at returning their committed capital. Market conditions also play a key role. Both buyout and venture funds return capital faster, the cheaper high-yield debt becomes, while venture funds return capital faster, the higher are returns on the Nasdaq Composite Index. Both effects are fairly large economically, with one-standard deviation changes in these variables leading to reductions from 18.8 quarters to 8.9 and 14 quarters in the pooled sample, respectively. The climate in the IPO market has no significant effect, but improved conditions in the M\&A market (as measured by an increase in the time-varying log number of M\&A deals completed in a fund's industry of specialization) lead to a large reduction in the time to returning $1 \mathrm{x}$ the committed capital, from the average of 18.8 to 11.2 quarters. This effect is concentrated among buyout funds.

In conclusion, these duration models provide supporting evidence for our hypothesis that fund behavior regarding capital return decisions is a function of shocks to the availability of investment opportunities, lags in the PEF market's ability to respond to such shocks, and changes in the degree of competition for deal flow, controlling for market conditions.

\section{Portfolio Company-level Analysis of Private Equity Funds}

\subsection{The Determinants of Individual Exit Decisions}

Having shown that fund-level decisions regarding capital returns are driven, at least in part, by investment opportunities and competition considerations, we now analyze fund behavior regarding individual exit decisions at the portfolio-company level. Thus the unit of observation in this section is a portfolio company rather than a fund. This provides a micro-level foundation for the analysis in the previous section.

Specifically, to see what determines how quickly a fund exits its investments, we model the log of time (in quarters) between a fund investing in a given portfolio company and the fund distributing cash 
or stock to its limited partners after exiting the investment (typically via an IPO or a sale). Note that when a fund exits an investment in several stages, we use the first transaction date. Adjusting for the fact that many of the more recent funds are right-censored and that failing investments are never exited, the average (median) holding period is 14.4 (12) quarters, with a range from one to 62 quarters.

As before, we estimate standard accelerated-time-to-failure models using maximum likelihood, first pooling all investments and then separately for the portfolio companies of buyout and venture funds. We treat investments that are not exited by the earlier of the end of our sample period or the tenth anniversary of a fund's raising as right-censored, with corresponding modifications to the loglikelihood function. Therefore, we estimate the model using the investments of all sample funds raised between 1981 and 2001. (Our results are qualitatively unaffected if we restrict the sample investments to those made by the mature funds raised in 1981-1993, which are not subject to right-censoring.)

We conjecture that holding periods are shorter (investments are exited faster), the better the investment environment in terms of available opportunities and the less competition the fund faces. We use the same proxies for these determinants as before, except that we measure per-industry disbursements by other funds in the quarter an investment was actually undertaken (as opposed to during a fund's first three years of existence). This more directly captures the degree of potential competition for the individual investment. The intuition for this proxy is that, holding the number of companies funded constant (i.e., investment opportunities), an increase in the amount of money the companies receive corresponds to an increase in valuations, all else equal, which is a measure of 'money chasing deals' (Gompers and Lerner (2000)).

We also control for three fund characteristics and two investment characteristics. First, venture funds may have longer holding periods than buyout funds to the extent that they invest in less mature companies that require more 'value-added' input by the venture capitalists. Second, larger funds may have a comparative advantage in seizing favorable exit opportunities, perhaps by virtue of having stronger relationships with top IPO underwriters. Third, Gompers (1996) identifies a fund's sequence number as a potentially important factor in the exit decision, with first-time funds having an incentive to take companies public too early ('grandstanding'). Fourth, larger investments potentially have more of an impact on a fund's profitability and IRR, and so may be exited sooner all else equal. Fifth, the fund year (counted from 1 to 10) in which an investment was made may influence holding periods to the extent that investments undertaken late in a fund's life need to be unwound when the fund's limited partnership agreement expires (typically after ten years).

The final, and possibly most important, set of controls relates to market conditions. We use the 
same four variables as in Table 4: the yield on high-yield corporate bonds, the quarterly return on the Nasdaq Composite Index, and conditions in the two primary exit markets: the IPO market and the M\&A market. The latter two are conditioned on a sample fund's industry of specialization. For all four variables, we expect that PEFs exit their investments faster, the better the market condition (i.e., low debt cost, high returns, strong IPO market, and active M\&A market). Unlike the fund and industry characteristics, market conditions change between the time an investment is undertaken and it is exited.

Table 5 reports the maximum-likelihood estimation results. The model $\chi^{2}$ statistics are large and highly significant in the pooled model as well as in the buyout-only and venture-only specifications, and the pseudo- $R^{2}$ indicate that our models capture a good deal of the variation in holding periods.

Across all three models, improvements in the investment environment, as captured by our proxy, lead to significantly faster exits. In the pooled specification, a one-standard-deviation increase in the $\log$ number of companies being funded reduces the holding period for the average portfolio company by one year, from 14.4 to 10.3 quarters, holding all other covariates in the pooled model constant. Consistent with investment opportunities being more plentiful during the heyday of the new-economy boom, the significantly negative coefficient estimated for the 'bubble' dummy shows that holding periods dropped substantially in 1999-2000.

Competition for deal flow plays an important role in determining a PEF's exit decisions: holding periods are significantly longer when a PEF faces greater competition, as captured by increases in the amount of capital available to a fund's direct competitors and the aggregate amount of money chasing deals in the same industry. As for the economic effects, one-standard-deviation increases in the amount of capital available to same-vintage-year funds and of capital chasing similar deals increase the average holding period in the pooled model from 14.4 to 19.9 and 19 quarters, respectively. In the subsample models, we find the same signs and roughly the same economic effects. Finally, the trend variable measuring the evolution of the PEF market has the expected negative coefficient, suggesting that funds raised earlier exited their investments faster, ceteris paribus. Again, note that this is not driven by right-censoring.

Among the controls, the most consistent effect comes from investment size: larger holdings are exited significantly faster, with a one-standard-deviation increase accelerating the exit decision by two and a half quarters in the pooled sample. Since shorter holding periods imply higher IRRs, ceteris paribus, this suggests that PEF managers focus their attention on those investments that have the largest impact on their fund returns. We also find that venture funds hold their investments significantly longer than do buyout funds, consistent with venture investments requiring more time to 
mature. Larger venture funds hold their investments significantly longer, which at first sight is odd: larger funds are more likely to hold later-stage investments which ceteris paribus should be exited faster. A possible explanation is that larger funds devote less time and attention to each portfolio company (assuming VC skills are scarce) which in turn 'mature' less quickly. We don't find any significant difference between first-time and follow-on funds, not even among venture funds, despite their incentive to 'grandstand'.

As one might expect, market conditions are an important determinant of the exit decision. For example, as high-yield debt becomes more expensive, exits are delayed. This effect is present both for buyout funds, which naturally are tied heavily to the leverage market, and for venture funds, be it because they focus on 'growth equity' or due to 'style drift'. Economically, the effect is large: in the pooled model, a one-standard deviation increase in bond yields lengthens mean holding periods from 14.4 to 21.9 quarters. An upturn in IPO activity also accelerates exits, especially among buyout funds, with mean holding periods falling from 14.4 to 11 quarters following a one standard deviation increase in log IPO volume. ${ }^{12}$ This provides complementary evidence to Barry, Muscarella, Peavy, and Vetsuypens (1990) and Lerner (1994) who document in a variety of ways that venture capitalists have market timing ability when taking companies public. Our result shows that the length of time they hold an investment is a direct function of the IPO market climate. The return on the Nasdaq Composite Index and conditions in the M\&A market do not influence holding periods.

\subsection{Investment Success}

Our data enable us to calculate investment-level returns for each portfolio company. The preferred return metric among private equity practitioners (though not among financial economists) is the multiple on investment, defined as $a b s$ (cash inflows/invested capital). Multiples give a general idea of the success rates of portfolio investments. They range from zero to $\infty$, with values less than one indicating capital losses. Given the nature of our data, multiples are net of the GPs' carried interest.

Funds of more recent vintages still hold many unexited investments as of the end of our sample period, for which multiples are necessarily zero. We therefore use the 73 mature funds raised between 1981 and 1993 to provide stylized facts for the investment success of private equity funds. Between them, these funds held 1,489 investments. The average portfolio company generated a multiple of 1.625. The distribution is significantly right-skewed: $54.9 \%$ of investments were written off (i.e. zero multiples), $14 \%$ lost money (i.e. multiples less than one), $11.8 \%$ were 'one-baggers' (i.e. multiples

\footnotetext{
${ }^{12}$ If we use market-wide IPO activity rather than conditioning IPO volume on Venture Economics industries, the effect becomes larger in economic magnitude, without affecting the other results.
} 
between one and two), $6.3 \%$ were 'two-baggers' (i.e. multiples between two and three), and the remaining $12.9 \%$ were at least 'three-baggers' (i.e. multiples of three or more). ${ }^{13}$ Broken up by fund type, we find that complete write-offs are much more common among venture funds $(75.3 \%)$ than among buyout funds (37.8\%), though buyout funds have many more losers (21.3\% vs. 5.4\%). This indicates that buyout investments - unlike venture investments - have some salvageable value even when they fail. Overall, the portfolio companies of buyout funds have somewhat larger average multiples (1.69 vs. 1.55), though the difference is not significant.

Multiples are hard to interpret, as they ignore the time value of money: doubling one's money over one year is better than doubling it over two years. Thus to assess the determinants of funds' investment success rates, we convert multiples into annualized returns using the holding period data analyzed in Section 5.1. ${ }^{14}$ Among mature funds, the average investment-level return is $-54.9 \%$, reflecting the large number of portfolio holdings that are written off.

A quirk of the data prevents us from calculating returns in excess of some benchmark. Consider an investment that is written off. We observe one or several dated cash outflows followed by no cash inflow. The multiple is zero and the return is $-100 \%$. The write-off date and so the length of the holding period are unknown, and thus we cannot calculate excess returns: without further information or assumptions, we don't know over what period to measure the benchmark return. In the analysis that follows, we therefore concentrate on raw returns. ${ }^{15}$ For the same reason, we do not include variables that are dated at the time of exit (such as conditions in the IPO or M\&A markets). ${ }^{16}$

What determines whether a particular portfolio company performs well or poorly? Obviously, performance will have a large idiosyncratic component, driven by technology risk, the quality of execution, market acceptance, competitors' reactions and so on. However, the framework proposed in this paper suggests that performance should also systematically be affected by changes in entrepreneurs' demand for capital, funds' ability to react by supplying capital at short notice, and competition for deal flow. Specifically, an improvement in investment opportunities should lead to

\footnotetext{
${ }^{13}$ Our distribution of multiples is broadly consistent with Cochrane's (2003) analysis of the fate of a sample of venture capital investments. Cochrane finds that $21.4 \%$ of the sample companies went public and $20.4 \%$ were acquired, with the remaining $58.2 \%$ classified as 'out of business' or 'still private'.

${ }^{14}$ We lose some observations as holding periods cannot be computed for all successful investments.

${ }^{15}$ The correlation between investment returns and contemporaneous Nasdaq returns conditional on success is negative in eight of the twenty vintage years 1981-2000, especially among the 1980s vintages. Controlling for Nasdaq returns in the regressions reported below (which entails focusing on exited investments only) does not change our results.

${ }^{16}$ Such variables can obviously only be measured for exited investments, reducing the sample size substantially. Conditional upon exit, we find that conditions in the IPO market have a significantly positive effect on returns, using the proxies introduced earlier (results not reported).
} 
higher returns for an existing fund that can satisfy the demand for capital before new PEFs enter the market. Conversely, tougher competition for deal flow should, all else equal, reduce performance.

We test these hypotheses by regressing investment returns on proxies for investment opportunities and competition for deal flow, controlling for fund characteristics (venture vs. buyout, fund sequence number, and fund size), investment characteristics (size of investment and fund year in which it was undertaken), and market conditions (the corporate bond yield at the time of investment). Note that as in Section 5.1, the unit of observation in this analysis is a portfolio company rather than a fund. We pool venture-backed and buyout investments; results for each sub-sample are similar and are not reported. Standard errors are adjusted for clustering on fund name (that is, investments undertaken by the same fund are not assumed to be independent).

The regressions are estimated using ordinary least-squares ${ }^{17}$ which - in contrast to the duration models estimated so far - provides no easy way to correct for right-censoring: funds raised more recently are less likely to have reached the point where investments can be exited, so their portfolio companies are more likely to have returns of $-100 \% .^{18}$ Therefore, we estimate the model over different samples, beginning with the investments held by funds raised in 1981-1993 (the mature funds in our dataset) and adding later vintage years one by one. As more vintages are added, sample size grows but the risk of right-censoring bias increases.

Table 6 reports the estimation results. Adjusted $R^{2}$ range from $7 \%$ to $12.7 \%$, suggesting that much of the variation in performance is due to factors that we have not controlled for, including presumably idiosyncratic factors. Improvements in investment opportunities have the predicted positive effect on returns, and this is generally significant across regressions. Among mature funds, for example, a onestandard deviation increase in the log number of companies funded in the same industry at the time a sample company received its first investment increases the average return by 19.8 percentage points, holding all other covariates at their sample means. Interestingly, we also find that investments made during the heyday of the new-economy boom in 1999-2000 subsequently had substantially lower returns. Note that the positive relation between investment opportunities and returns is consistent with the framework of Section 2 and the results of Section 5.1. That is, if existing PEFs are able to take

\footnotetext{
${ }^{17}$ We obtain qualitatively identical results in probits of the likelihood of 'success' vs. 'failure', where 'success' is alternately defined as a multiple that exceeds 1,2 , or 3 .

${ }^{18}$ Alternatively, one might consider estimating censored regressions (such as a Tobit). This is problematic for two reasons. First, we face the practical problem of which investments in our data have zero multiples (-100\% returns) because they have been written off (so their true multiple is indeed zero), and which have zero multiples because we don't observe them long enough for them to pay off (right-censoring). Second, censored regressions (unlike OLS) are not robust to departures from the assumption that the underlying distribution is normal (see Goldberger (1983)). Normality is not a good description of the distribution of investment returns.
} 
advantage of 'sticky' capital markets, then their returns on investment should reflect this competitive advantage.

Tougher competition for deal flow, on the other hand, reduces returns as conjectured: the more money is available to a fund's main competitors, and the more money is invested in the same industry, the lower are returns. To illustrate, a one-standard deviation increase in the amount invested in other companies in the industry reduces returns by 12 percentage points, using the estimates for vintage years 1981-1993. The interpretation of this result is that, holding investment opportunities fixed (as measured by number of companies funded), the increase in money chasing deals reduces returns by a considerable amount. Our finding also complements Gompers and Lerner's (2000) analysis of the positive impact of capital inflows into venture funds on the 'pre-money valuations' of investments such funds undertake. Arguably, our results based on investment-level returns provide a clearer picture of the negative effect of competition on funds' success rates, since Gompers and Lerner do not know what fraction of the equity VCs acquire in return for their investments.

Taken together, our evidence of a relation between returns and both investment opportunities and competition strongly support the central hypotheses proposed in this paper. Note that Tables 3 through 5 show that private equity fund managers time their investment and exit decisions in response to competitive conditions in the PEF market. A corollary of this is that the PEFs' actions should be reflected in the success rate of these investments. Table 6 demonstrates that this is the case.

\section{Final Remarks}

What factors explain the investment behavior of private equity fund managers? This paper proposes a framework based on an imperfectly competitive market for private equity in which demand for private equity varies over time and the supply of private equity is 'sticky' in the short run. Increases in demand can, in the short run, only be met by existing funds which accelerate their investment flows and earn excess returns. Increases in supply lead to tougher competition for deal flow, and private equity fund managers respond by cutting their investment spending. Supply increases possibly indicate overheating accompanied by poorer performance (e.g., Kaplan and Stein (1993) and Gompers and Lerner (2000)).

Using a unique dataset of private equity funds over the last two decades, we document evidence consistent with this framework by estimating the determinants of the draw down and exit decisions of funds' investments throughout their life. Controlling for fund characteristics and market conditions, we show that the competitive environment facing fund managers plays an important role in how they manage their investments. During periods in which investment opportunities are good, existing funds 
invest their capital and exit their investments more quickly, taking advantage of the favorable business climate. This tends to lead to better returns on their investments. In contrast, when facing greater competition from other private equity funds, fund managers draw down their capital more slowly and hold their investments for longer periods of time. Returns on investment undertaken when competition was tougher are ultimately significantly lower.

The model of the private equity market described in this paper has implications for the literature on fund performance. Conditioning on PEF compensation being homogenous across funds, investors with access to funds that are in a position to take advantage of the stickiness of private equity capital should earn excess expected returns. Remaining investors earn normal risk-adjusted rates of return. The exception, however, is the set of investors who provide capital during overheated environments in which potentially 'too much money chases deals'. These investors, of course, earn poor returns. Evidence presented in Table 6 supports this view at the individual investment level. Moreover, this model and the investment behavior of fund managers documented here coincide with the recent literature that provides evidence of the determinants of private equity fund-level performance (see, for example, Kaplan and Stein (1993), Gompers and Lerner (2000), Kaplan and Schoar (2003) and Jones and Rhodes-Kropf (2003), among others).

But there are many questions that remain unanswered. For instance, does the cross-sectional and time-series distribution of PEF returns imply rational behavior on the part of investors? At a general level, this depends on investors' ability to predict the current level of competition for PEF capital and forecast future periods of investment opportunities. Consider Kaplan and Schoar's (2003) result that returns from follow-on funds are persistent and exceed those of first-time funds (also see our Table 6 for similar evidence at the individual investment level). Investors may be acting rationally by investing in first-time funds to the extent that it provides them an option (perhaps not available to all investors) of investing in a follow-on fund if the PEF is successful. To fully address this issue, the results in this paper suggest one possible factor, namely the degree of competition in the market over the life of the fund. A complete answer, however, needs to incorporate the risk characteristics of the fund as well as the premium for liquidity (if any) which may vary across funds. 


\section{References}

Barry, Christopher B., Chris Muscarella, John W. Peavy III, and Michael R. Vetsuypens, 1990. 'The role of venture capital in the creation of public companies: Evidence from the going public process.' Journal of Financial Economics 27, 447-471.

Bengtsson, Ola, Steven N. Kaplan, Frederic Martel, and Per Strömberg, 2002. 'Investment screening and market conditions: Evidence from venture capital.' Unpublished working paper, University of Chicago.

Black, Bernard S., and Ronald J. Gilson, 1998. 'Venture capital and the structure of capital markets: banks versus stock markets.' Journal of Financial Economics 47, 243-277.

Brav, Alon, and Paul A. Gompers, 2003. 'The role of lock-ups in initial public offerings.' Review of Financial Studies 16, 1-29.

Cochrane, John, 2003. 'The risk and return of venture capital.' Unpublished working paper, University of Chicago.

Goldberger, A.S., 1983. 'Abnormal selection bias' in: S. Karlin, T. Amemiya, and L.A. Goodman (eds.), Studies in Econometrics, Time Series and Multivariate Statistics, 67-84. Academic Press.

Gompers, Paul A., 1995. 'Optimal investment, monitoring, and the staging of venture capital.' Journal of Finance 50, 1461-1490.

Gompers, Paul A., 1996. 'Grandstanding in the venture capital industry.' Journal of Financial Economics 43, 133-156.

Gompers, Paul A., and Josh Lerner, 1996. 'The use of covenants: An analysis of venture partnership agreements.' Journal of Law and Economics 39, 463-498.

Gompers, Paul A., and Josh Lerner, 1998. 'What drives fundraising?' Brookings Papers on Economic Activity: Microeconomics, 149-92.

Gompers, Paul A., and Josh Lerner, 1999a. 'An analysis of compensation in the U.S. venture capital partnership.’ Journal of Financial Economics 51, 3-44.

Gompers, Paul A., and Josh Lerner, 1999b. The Venture Capital Cycle. MIT Press.

Gompers, Paul A., and Josh Lerner, 2000. 'Money chasing deals? The impact of fund inflows on private equity valuations.' Journal of Financial Economics 55, 281-325.

Gorman, Michael, and William A. Sahlman, 1989. 'What do venture capitalists do?' Journal of Business Venturing 4, 231-248.

Hellmann, Thomas J., and Manju Puri, 2002. 'Venture capital and the professionalization of start-up firms: Empirical evidence.' Journal of Finance 57, 169-197. 
Inderst, Roman, and Holger Mueller, 2003. 'The effect of capital market characteristics on the value of start-up firms.' Journal of Financial Economics, forthcoming

Jones, Charles M., and Matthew Rhodes-Kropf, 2002. 'The price of diversifiable risk in venture capital and private equity.' Unpublished working paper, Columbia University.

Kalbfleisch, J.D., and R.L. Prentice, 1980. The Statistical Analysis of Failure Time Data. John Wiley $\&$ Sons, New York.

Kaplan, Steven N., and Antoinette Schoar, 2003. 'Private equity returns: Persistence and capital flows.' Unpublished working paper, University of Chicago.

Kaplan, Steven N., and Jeremy Stein, 1993. 'The evolution of buyout pricing and financial structure in the 1980s.' Quarterly Journal of Economics 108, 313-358.

Kaplan, Steven N., and Per Strömberg, 2003. 'Financial contracting theory meets the real world: Evidence from venture capital contracts.' Review of Economic Studies 70, 281-315.

Lerner, Josh, 1994. 'Venture capitalists and the decision to go public.' Journal of Financial Economics 35, 293-316.

Lerner, Josh, and Antoinette Schoar, 2003. 'The illiquidity puzzle: Theory and evidence from private equity.' Journal of Financial Economics, forthcoming.

Loughran, Tim, Jay R. Ritter, and Kristian Rydqvist, 1994. 'Initial public offerings: International insights.' Pacific Basin Finance Journal 2, 165-199.

Moskowitz, Toby, and Annette Vissing-Jørgensen, 2002. 'The returns to entrepreneurial investment: A private equity premium puzzle?' American Economic Review 92, 745-778.

Palepu, Krishna, 1990. 'Consequences of leveraged buyouts.' Journal of Financial Economics 27, 247262.

Sahlman, William A., 1990. 'The structure and governance of venture-capital organizations.' Journal of Financial Economics 27, 473-521.

Sahlman, William A., and Howard Stevenson, 1986. 'Capital market myopia.' Journal of Business Venturing 1, 7-30.

Wermers, R., 1999. 'Mutual fund herding and the impact on stock prices.' Journal of Finance 54, 581622. 


\section{Figure 1. Draw down and distribution rates by fund year}

The figure shows average cumulative draw downs for each year of a fund's life (counted from 1 to 10), divided by committed capital; average cumulative distributions divided by committed capital; and net capital gains (the difference between distributions and draw downs). The number of funds available for calculating these averages decreases over the fund years, as not every fund has completed a ten-year run of operation. The average fund draws down $16.28 \%, 20.35 \%$, and $20.15 \%$ of committed capital in its first three years of operation. At the end of its fourth year, it is $72.64 \%$ invested, and at the end of its expected life (year 10) it is $93.62 \%$ invested. There are no further draw downs beyond year 10. It takes around seven years for committed capital to be returned. Funds sometimes have further distributions beyond year 10, which are not shown.

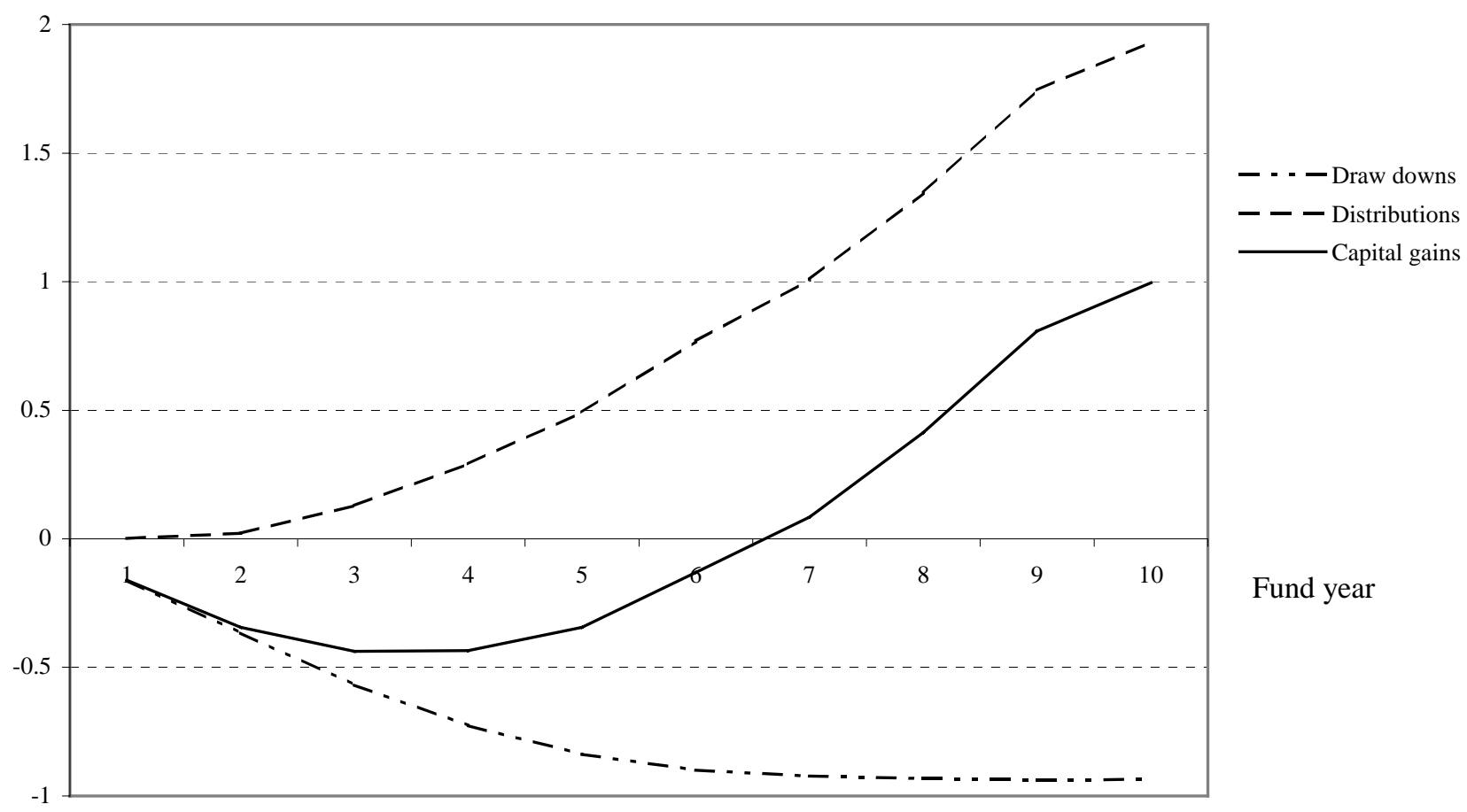




\section{Table 1. Sample overview}

The sample consists of private equity and venture capital funds raised between 1981 and 2001 (the 'vintage years'). To protect the identity of the Limited Partner, we have agreed not to disclose the number of newly raised funds the Limited Partner invested in after 1993. We refer to the 73 funds raised before 1993 as 'mature' funds. VC funds are those identified as 'Venture Capital' by Venture Economics. Most non-venture funds are flagged as 'Buyout' (90.4\%); the remainder are flagged as 'Generalist Private Equity' (3.8\%), 'Mezzanine' (4.8\%), and 'Other Private Equity' (1\%). Fund size is the capital committed by investors to a fund in all closings, as reported by Venture Economics and corrected by us where needed using partnership reports prepared by the fund managers. Total fund size is the aggregate amount raised by all sample funds. The 'VE universe' refers to all funds raised in the relevant sample period according to Venture Economics that are headquartered in the same countries as our sample funds (the U.S. and certain countries in Europe and Latin America). Commitment is the Limited Partner's capital commitment to the funds. Total commitment is the aggregate commitment by the Limited Partner. Mean commitment is equally weighted. All monetary numbers are in nominal U.S. dollars.

\begin{tabular}{|c|c|c|c|c|c|c|}
\hline & & 981-2001 & & & 981-1993 & \\
\hline & all funds & $\begin{array}{l}\text { buyout } \\
\text { funds }\end{array}$ & VC funds & all funds & $\begin{array}{l}\text { buyout } \\
\text { funds }\end{array}$ & $\mathrm{VC}$ funds \\
\hline No. of funds & $*$ & * & $*$ & 73 & 54 & 19 \\
\hline Fund type & & & & & & \\
\hline$\%$ that are $\mathrm{VC}$ funds (by number) & 24.9 & & & 26.0 & & \\
\hline$\%$ that are $\mathrm{VC}$ funds (by fund size) & 14.8 & & & 11.8 & & \\
\hline Fund size $(\$ \mathrm{~m})$ & & & & & & \\
\hline Total & 207,011 & 176,443 & 30,568 & 36,704 & 32,381 & 4,322 \\
\hline Mean & $*$ & $*$ & $*$ & 502.8 & 599.7 & 227.5 \\
\hline Median & 367.5 & 452.0 & 200.0 & 233.0 & 271.5 & 75.0 \\
\hline$\%$ of VE universe covered (by capital) & 17.5 & 29.3 & 6.3 & 20.2 & 27.7 & 3.7 \\
\hline Commitment $(\$ \mathrm{~m})$ & & & & & & \\
\hline Total & $5,459.4$ & $4,772.0$ & 687.5 & $1,107.0$ & $1,020.8$ & 86.2 \\
\hline Mean & $*$ & $*$ & $*$ & 15.2 & 18.9 & 4.5 \\
\hline Median & 10.0 & 12.5 & 5.0 & 7.0 & 10.0 & 3.2 \\
\hline Commitment/fund size $(\%)$ & & & & & & \\
\hline Mean & 4.7 & 4.1 & 6.6 & 4.6 & 4.2 & 5.9 \\
\hline Median & 3.3 & 3.2 & 3.7 & 3.7 & 3.4 & 5.6 \\
\hline Fund sequence number (as $\%$ of funds & & & & & & \\
\hline first-time funds & 27.7 & 26.5 & 31.3 & 34.8 & 33.3 & 38.9 \\
\hline second-time funds & 21.0 & 23.0 & 14.9 & 18.8 & 21.6 & 11.1 \\
\hline third-time funds & 11.6 & 12.0 & 10.4 & 8.7 & 7.8 & 11.1 \\
\hline later funds & 39.7 & 38.5 & 43.3 & 37.7 & 37.3 & 38.9 \\
\hline
\end{tabular}




\section{Table 2A. Draw downs by vintage year}

Fund managers typically draw down the limited partners' capital commitment not when the fund is raised but when they wish to invest in a portfolio company. The average fund in our sample has drawn down $67.32 \%$ of committed capital. However, this understates draw downs as the more recent funds in the sample are not yet fully invested. Therefore, we also report draw down schedules for the 73 funds raised between 1981 and 1993.

\begin{tabular}{|c|c|c|c|c|c|c|}
\hline \multirow[b]{2}{*}{$\begin{array}{c}\text { Vintage } \\
\text { Year }\end{array}$} & \multicolumn{4}{|c|}{ All funds } & \multirow[b]{2}{*}{$\begin{array}{r}\text { Buyout funds } \\
\text { Average } \\
\text { draw downs / } \\
\text { committed } \\
\text { capital }\end{array}$} & \multirow{2}{*}{$\begin{array}{r}\text { VC funds } \\
\text { Average } \\
\text { draw downs / } \\
\text { committed } \\
\text { capital } \\
\end{array}$} \\
\hline & $\begin{array}{l}\text { No. of } \\
\text { funds }\end{array}$ & $\begin{array}{r}\text { Average } \\
\text { draw downs / } \\
\text { committed } \\
\text { capital } \\
\end{array}$ & $\begin{array}{r}\text { Fraction of } \\
\text { funds that are } \\
70 \% \text { invested }\end{array}$ & $\begin{array}{r}\text { Fraction of } \\
\text { funds that are } \\
80 \% \text { invested }\end{array}$ & & \\
\hline 1981-2001 & $*$ & 0.6732 & 0.556 & 0.495 & 0.6671 & 0.6916 \\
\hline 1981-1993 & 73 & 0.9474 & 0.959 & 0.890 & 0.9466 & 0.9498 \\
\hline 1981 & 1 & 0.9991 & 1.000 & 1.000 & 0.9991 & n.a. \\
\hline 1983 & 2 & 0.8973 & 1.000 & 0.500 & 1.0000 & 0.7947 \\
\hline 1984 & 5 & 0.9688 & 1.000 & 1.000 & 1.0091 & 0.9085 \\
\hline 1985 & 4 & 1.0112 & 1.000 & 1.000 & 1.0149 & 1.0000 \\
\hline 1986 & 6 & 1.0003 & 1.000 & 1.000 & 1.0003 & 1.0000 \\
\hline 1987 & 8 & 0.8654 & 0.750 & 0.625 & 0.8555 & 0.8819 \\
\hline 1988 & 12 & 0.9780 & 1.000 & 1.000 & 0.9760 & 1.0000 \\
\hline 1989 & 11 & 0.9517 & 1.000 & 0.909 & 0.9410 & 1.0000 \\
\hline 1990 & 4 & 0.9217 & 1.000 & 0.750 & 0.8647 & 0.9787 \\
\hline 1992 & 6 & 0.9027 & 0.833 & 0.833 & 0.8588 & 0.9904 \\
\hline 1993 & 14 & 0.9462 & 1.000 & 0.929 & 0.9397 & 0.9627 \\
\hline 1994 & * & 0.9313 & 0.938 & 0.875 & 0.9219 & 0.9969 \\
\hline 1995 & $*$ & 0.9101 & 1.000 & 0.923 & 0.8913 & 1.0133 \\
\hline 1996 & $*$ & 0.9016 & 0.944 & 0.889 & 0.8928 & 0.9321 \\
\hline 1997 & $*$ & 0.7632 & 0.618 & 0.441 & 0.6784 & 0.9668 \\
\hline 1998 & $*$ & 0.6511 & 0.400 & 0.400 & 0.6454 & 0.6786 \\
\hline 1999 & $*$ & 0.4119 & 0.100 & 0.025 & 0.3598 & 0.6201 \\
\hline 2000 & $*$ & 0.1906 & 0.000 & 0.000 & 0.1970 & 0.1785 \\
\hline 2001 & $*$ & 0.1831 & 0.000 & 0.000 & n.a. & 0.1831 \\
\hline
\end{tabular}


Table 2B. Capital distributions by vintage year

Funds are typically ten-year limited partnerships, with possible extensions by a few years subject to the limited partners' approval. Following liquidity events (such as an IPO), capital is returned to the limited partners in the form of cash or stock distributions. In the latter case, the LP may either sell the stock directly or hold it as a public market investment. We record only stock distributions that are sold (as virtually all are in our sample). At the end of the fund's life, the general partner 'liquidates' the fund by selling all remaining assets and distributing the cash to the limited partners. The liquidation phase can potentially take a few years. The panel shows average cumulative distributions divided by invested and by committed capital for all funds raised between 1981 and 2001, and 1981 and 1993, and by vintage year.

\begin{tabular}{|c|c|c|c|c|c|}
\hline \multirow[b]{2}{*}{$\begin{array}{c}\text { Vintage } \\
\text { Year }\end{array}$} & \multicolumn{3}{|c|}{ All funds } & \multirow{2}{*}{$\begin{array}{r}\text { Buyout funds } \\
\text { Average } \\
\text { distributions / } \\
\text { capital invested }\end{array}$} & \multirow{2}{*}{$\begin{array}{r}\text { VC funds } \\
\text { Average } \\
\text { distributions / } \\
\text { capital invested }\end{array}$} \\
\hline & $\begin{array}{l}\text { No. of } \\
\text { funds }\end{array}$ & $\begin{array}{r}\text { Average } \\
\text { distributions / } \\
\text { capital invested }\end{array}$ & $\begin{array}{r}\text { Average } \\
\text { distributions / } \\
\text { committed } \\
\text { capital }\end{array}$ & & \\
\hline $1981-2001$ & $*$ & 1.0683 & 0.9434 & 1.0307 & 1.1802 \\
\hline 1981-1993 & 73 & 2.5913 & 2.4517 & 2.5639 & 2.6693 \\
\hline 1981 & 1 & 3.2780 & 3.2751 & 3.2780 & n.a. \\
\hline 1983 & 2 & 3.2168 & 2.9249 & 3.5901 & 2.8435 \\
\hline 1984 & 5 & 3.0794 & 2.9797 & 3.5046 & 2.4415 \\
\hline 1985 & 4 & 5.1357 & 5.1416 & 5.7111 & 3.4095 \\
\hline 1986 & 6 & 3.8571 & 3.8577 & 3.7980 & 4.1528 \\
\hline 1987 & 8 & 2.6453 & 2.3634 & 2.8899 & 2.2378 \\
\hline 1988 & 12 & 2.0259 & 1.9661 & 1.9999 & 2.3123 \\
\hline 1989 & 11 & 2.6084 & 2.4332 & 2.3998 & 3.5469 \\
\hline 1990 & 4 & 1.9637 & 1.7902 & 1.6966 & 2.2308 \\
\hline 1992 & 6 & 1.8777 & 1.6396 & 2.1632 & 1.3067 \\
\hline 1993 & 14 & 1.9346 & 1.7836 & 1.4851 & 3.0584 \\
\hline 1994 & $*$ & 1.3123 & 1.1882 & 1.4227 & 0.5394 \\
\hline 1995 & * & 1.2377 & 1.1478 & 0.9561 & 2.7868 \\
\hline 1996 & $*$ & 0.8367 & 0.7804 & 0.7657 & 1.0853 \\
\hline 1997 & * & 0.5130 & 0.4348 & 0.3942 & 0.7982 \\
\hline 1998 & $*$ & 0.5966 & 0.4377 & 0.4547 & 1.2820 \\
\hline 1999 & * & 0.1995 & 0.0918 & 0.2107 & 0.1546 \\
\hline 2000 & * & 0.1187 & 0.0130 & 0.0849 & 0.1757 \\
\hline 2001 & * & 0.0001 & 0.0000 & n.a. & 0.0001 \\
\hline
\end{tabular}




\section{Table 3. The determinants of draw-down rates}

The dependent variable is the log of the time (in quarters) between a fund being raised and it having drawn down at least X\% of its committed capital. We use three cutoffs for X: 70, 80 and 90\%. The explanatory variables are listed in the table and discussed more fully in the text. We estimate accelerated-time-to-failure models using maximum likelihood estimators that are corrected for the right-censoring caused by funds leaving our sample before they are fully invested. We thus include all sample funds raised between 1981 and 2001 in the analysis. The error is assumed to have an exponential distribution with mean $\beta_{0}$ (the constant). This model is identical to a proportional-hazard duration model, and coefficients can easily be converted into hazard ratios. The intercepts are not reported. We use ${ }^{* * *},{ }^{* *}$, and ${ }^{*}$ to denote significance at the $1 \%, 5 \%$, and $10 \%$ level (two-sided), respectively.

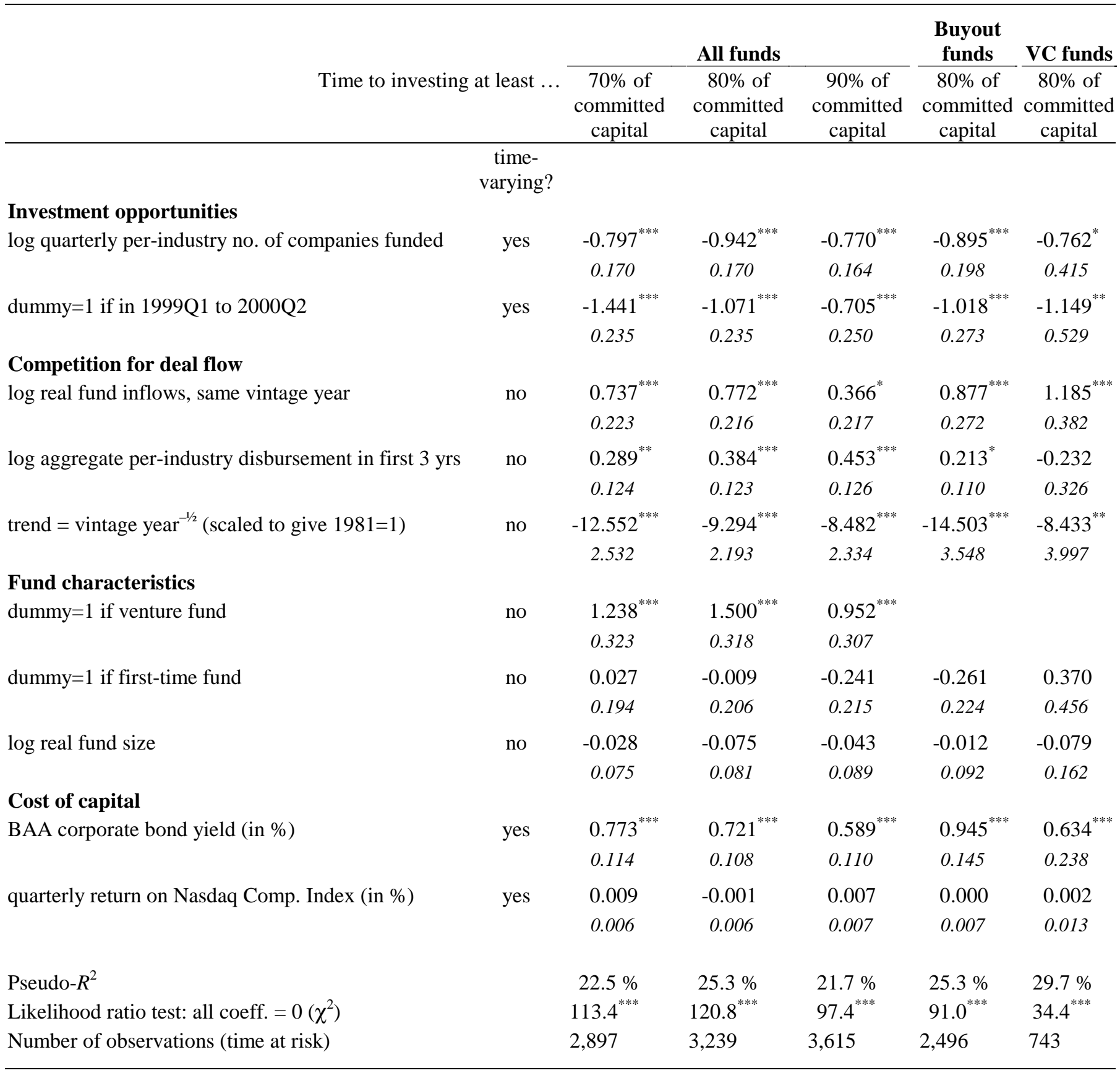




\section{Table 4. The determinants of capital returns}

The dependent variable is the log of the time (in quarters) between a fund being raised and it having returned at least $\mathrm{M}$ times its committed capital. We use three cutoffs for $\mathrm{M}$ : $1 \mathrm{x}, 1.5 \mathrm{x}$ and $2 \mathrm{x}$. The explanatory variables are listed in the table. We estimate accelerated-time-to-failure models using maximum likelihood estimators that are corrected for the right-censoring caused by funds leaving our sample before they are fully invested. We thus include all sample funds raised between 1981 and 2001 in the analysis. The error is assumed to have an exponential distribution with mean $\beta_{0}$ (the constant). This model is identical to a proportional-hazard duration model, and coefficients can easily be converted into hazard ratios. Intercepts are not reported. The intercepts are not reported. We use ${ }^{* * *},{ }^{* *}$, and ${ }^{*}$ to denote significance at the 1\%, 5\%, and 10\% level (two-sided), respectively.

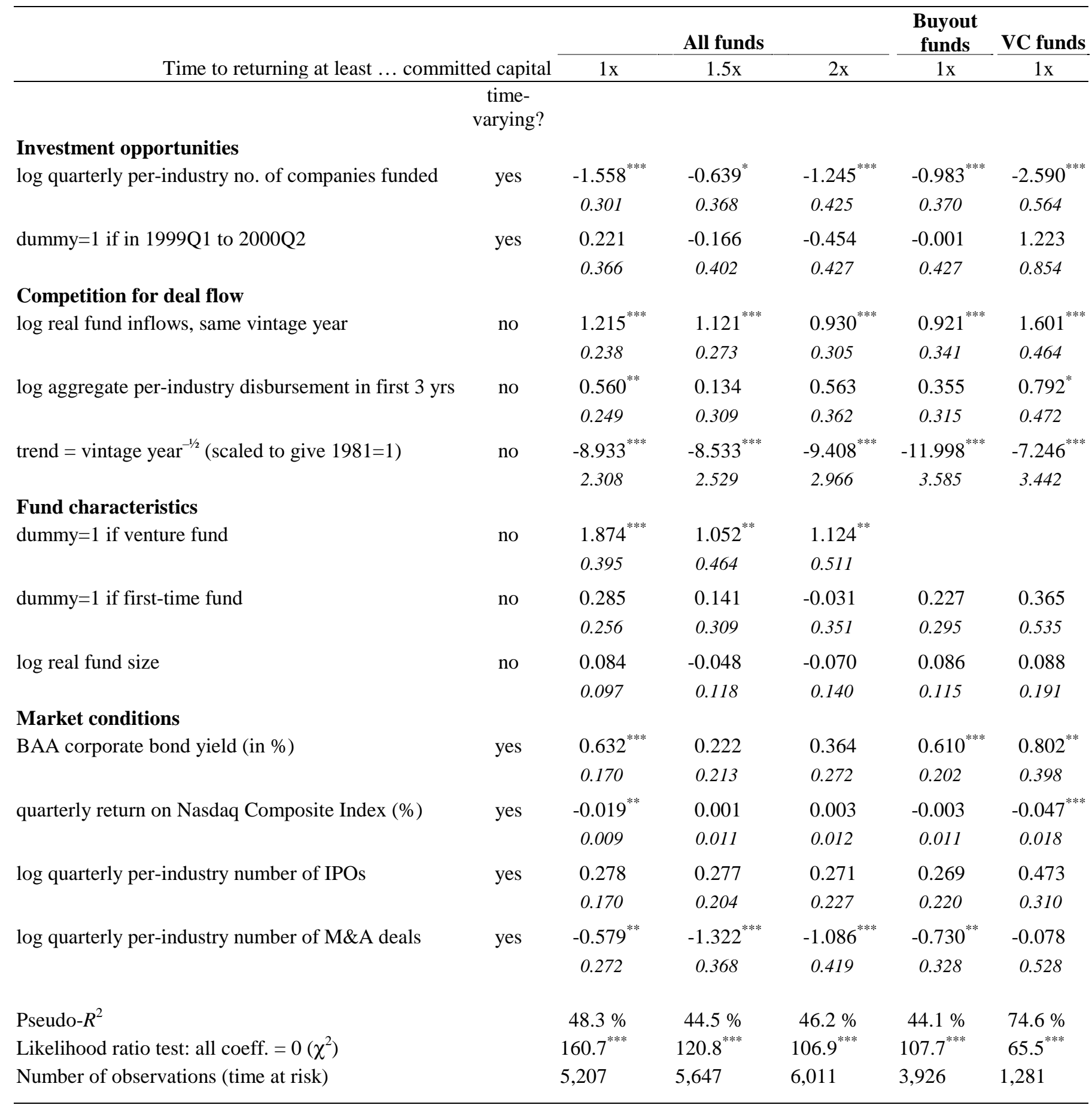


Table 5. The determinants of holding periods

The dependent variable is the log of the time (in quarters) between a fund investing in a given portfolio company and the fund distributing cash or stock to its LPs after exiting the investment (typically via an IPO or a sale). If the fund exits the investment in several stages, we use the first transaction date. Investments that are not exited by the earlier of the end of our sample period or the tenth anniversary of a fund's creation are treated as right-censored, with appropriate modifications to the log-likelihood function. We thus include the investments of all sample funds raised between 1981 and 2001 in the analysis. The explanatory variables are listed in the table. We estimate accelerated time-to-failure models using maximum likelihood estimators. The error is assumed to have an exponential distribution with mean $\beta_{0}$ (the constant). This model is identical to a proportionalhazard duration model, and coefficients can easily be converted into hazard ratios. The intercepts are not reported. Standard errors, shown in italics, are adjusted for clustering on fund name (that is, investments undertaken by the same fund are not assumed to be independent). We use ${ }^{* * * * *},{ }^{*}$, and ${ }^{*}$ to denote significance at the $1 \%, 5 \%$, and $10 \%$ level (two-sided), respectively.

\begin{tabular}{|c|c|c|c|c|}
\hline & $\begin{array}{c}\text { time- } \\
\text { varying? }\end{array}$ & All funds & $\begin{array}{l}\text { Buyout } \\
\text { funds }\end{array}$ & VC funds \\
\hline \multicolumn{5}{|l|}{ Investment opportunities } \\
\hline \multirow[t]{2}{*}{ log quarterly per-industry no. of companies funded } & yes & $-0.375^{* * *}$ & $-0.344^{* * *}$ & $-0.423^{* *}$ \\
\hline & & 0.105 & 0.122 & 0.216 \\
\hline \multirow[t]{2}{*}{ dummy=1 if in $1999 \mathrm{Q} 1$ to $2000 \mathrm{Q} 2$} & yes & $-0.624^{* * *}$ & $-0.584^{* * *}$ & $-0.842^{* * *}$ \\
\hline & & 0.125 & 0.141 & 0.261 \\
\hline \multicolumn{5}{|l|}{ Competition for deal flow } \\
\hline \multirow[t]{2}{*}{$\log$ real fund inflows, same vintage year } & no & $0.350^{* *}$ & $0.335^{*}$ & $0.563^{* *}$ \\
\hline & & 0.150 & 0.201 & 0.236 \\
\hline \multirow[t]{2}{*}{$\log$ real per-industry disbursements at time of investment } & no & $0.184^{* * *}$ & $0.178^{* * *}$ & $0.169^{* *}$ \\
\hline & & 0.031 & 0.033 & 0.086 \\
\hline \multirow[t]{2}{*}{ trend $=$ vintage year $^{-1 / 2}($ scaled to give $1981=1)$} & no & $-6.477^{* * *}$ & $-6.144^{* * *}$ & $-6.976^{* * *}$ \\
\hline & & 1.466 & 2.159 & 1.746 \\
\hline \multicolumn{5}{|l|}{ Fund and investment characteristics } \\
\hline \multirow[t]{2}{*}{ dummy $=1$ if venture fund } & no & $0.956^{* * *}$ & & \\
\hline & & 0.206 & & \\
\hline \multirow[t]{2}{*}{ dummy $=1$ if first-time fund } & no & -0.044 & 0.001 & -0.038 \\
\hline & & 0.152 & 0.180 & 0.257 \\
\hline \multirow[t]{2}{*}{$\log$ real fund size } & no & 0.015 & -0.024 & $0.141^{*}$ \\
\hline & & 0.062 & 0.071 & 0.075 \\
\hline \multirow[t]{2}{*}{$\log$ real investment cost } & no & $-0.122^{* * *}$ & $-0.104^{* *}$ & $-0.232^{* * *}$ \\
\hline & & 0.037 & 0.042 & 0.065 \\
\hline \multirow[t]{2}{*}{ fund year in which investment was made (1 to 10 ) } & no & 0.054 & 0.040 & 0.109 \\
\hline & & 0.036 & 0.037 & 0.096 \\
\hline \multicolumn{5}{|l|}{ Market conditions } \\
\hline \multirow[t]{2}{*}{ BAA corporate bond yield (in \%) } & yes & $0.524^{* * *}$ & $0.517^{* * *}$ & $0.527^{* * *}$ \\
\hline & & 0.078 & 0.095 & 0.130 \\
\hline \multirow[t]{2}{*}{ quarterly return on Nasdaq Composite Index (\%) } & yes & 0.002 & 0.003 & -0.002 \\
\hline & & 0.003 & 0.003 & 0.007 \\
\hline \multirow[t]{2}{*}{ log quarterly per-industry number of IPOs } & yes & $-0.220^{* * *}$ & $-0.290^{* * *}$ & 0.021 \\
\hline & & 0.052 & 0.060 & 0.108 \\
\hline \multirow[t]{2}{*}{$\log$ quarterly per-industry number of M\&A deals } & yes & -0.113 & -0.159 & -0.082 \\
\hline & & 0.098 & 0.125 & 0.139 \\
\hline Pseudo- $R^{2}$ & & $14.7 \%$ & $13.8 \%$ & $18.6 \%$ \\
\hline Likelihood ratio test: all coeff. $=0\left(\chi^{2}\right)$ & & $333.6^{* * *}$ & $290.9^{* * *}$ & $118.6^{* * *}$ \\
\hline Number of observations (time at risk) & & 30,189 & 22,407 & 7,782 \\
\hline
\end{tabular}




\section{Table 6. Determinants of investment returns}

The dependent variable is the annualized return on investment for each portfolio company, defined as $a b s$ (cash inflows/invested capital) raised to the power (1/holding period), minus 1 . The explanatory variables are listed in the table. We estimate ordinary least-square regressions over different samples, beginning with all funds raised between 1981 and 1993 (the mature funds in our dataset) and adding later vintage years one by one. Funds raised more recently are less likely to have reached the point where investments can be exited, so their portfolio companies are more likely to have $-100 \%$ returns. Standard errors, shown in italics, are adjusted for clustering on fund name (that is, investments undertaken by the same fund are not assumed to be independent). We use ${ }^{* * * *},{ }^{* *}$, and ${ }^{*}$ to denote significance at the $1 \%, 5 \%$, and $10 \%$ level (two-sided), respectively.

\begin{tabular}{|c|c|c|c|c|c|c|}
\hline Vintage years: & $\begin{array}{c}1981 \\
\text { to } 1993\end{array}$ & $\begin{array}{l}1981 \\
\text { to } 1994\end{array}$ & $\begin{array}{l}1981 \\
\text { to } 1995\end{array}$ & $\begin{array}{c}1981 \\
\text { to } 1996\end{array}$ & $\begin{array}{l}1981 \\
\text { to } 1997\end{array}$ & $\begin{array}{c}1981 \\
\text { to } 1998\end{array}$ \\
\hline \multicolumn{7}{|l|}{ Investment opportunities } \\
\hline \multirow[t]{2}{*}{ log per-industry no. of companies funded } & $0.262^{* * *}$ & $0.216^{* * *}$ & $0.119^{*}$ & 0.079 & $0.088^{*}$ & $0.084^{* *}$ \\
\hline & 0.069 & 0.068 & 0.062 & 0.055 & 0.046 & 0.041 \\
\hline \multirow[t]{2}{*}{ dummy=1 if investment made in $1999 \mathrm{Q} 1$ to $2000 \mathrm{Q} 2$} & $-0.878^{* * *}$ & $-0.629^{* * *}$ & $-0.551^{* * *}$ & $-0.373^{* * *}$ & $-0.192^{* * *}$ & $-0.096^{* *}$ \\
\hline & 0.301 & 0.188 & 0.148 & 0.093 & 0.059 & 0.045 \\
\hline \multicolumn{7}{|l|}{ Competition for deal flow } \\
\hline \multirow[t]{2}{*}{ log real fund inflows, same vintage year } & 0.091 & 0.010 & -0.078 & -0.079 & $-0.182^{* * *}$ & $-0.210^{* * *}$ \\
\hline & 0.066 & 0.068 & 0.065 & 0.061 & 0.045 & 0.040 \\
\hline \multirow[t]{2}{*}{ log real per-industry disbursements at time of investment } & $-0.104^{* * *}$ & $-0.095^{* *}$ & $-0.061^{*}$ & -0.052 & $-0.063^{* *}$ & $-0.066^{* *}$ \\
\hline & 0.039 & 0.040 & 0.038 & 0.034 & 0.029 & 0.026 \\
\hline \multirow{2}{*}{ trend $=$ vintage year ${ }^{-1 / 2}($ scaled to give $1981=1)$} & -0.176 & -0.177 & -0.293 & 0.234 & 0.016 & 0.085 \\
\hline & 0.656 & 0.689 & 0.655 & 0.604 & 0.527 & 0.494 \\
\hline \multicolumn{7}{|l|}{ Fund and investment characteristics } \\
\hline \multirow[t]{2}{*}{ dummy $=1$ if venture fund } & $-0.558^{* * *}$ & $-0.556^{* * *}$ & $-0.514^{* * *}$ & $-0.465^{* * *}$ & $-0.512^{* * *}$ & $-0.521^{* * *}$ \\
\hline & 0.097 & 0.100 & 0.094 & 0.083 & 0.065 & 0.057 \\
\hline \multirow[t]{2}{*}{ dummy $=1$ if first-time fund } & $-0.152^{* *}$ & $-0.113^{*}$ & -0.078 & -0.082 & -0.051 & -0.034 \\
\hline & 0.066 & 0.064 & 0.058 & 0.054 & 0.046 & 0.043 \\
\hline \multirow[t]{2}{*}{ log real fund size } & -0.006 & 0.022 & 0.032 & 0.024 & 0.023 & 0.015 \\
\hline & 0.023 & 0.024 & 0.022 & 0.020 & 0.017 & 0.015 \\
\hline \multirow[t]{2}{*}{ log real investment cost } & $0.039^{* * *}$ & $0.031^{* *}$ & $0.041^{* * *}$ & $0.040^{* * *}$ & $0.039^{* * * *}$ & $0.032^{* * *}$ \\
\hline & 0.013 & 0.014 & 0.013 & 0.011 & 0.010 & 0.009 \\
\hline \multirow[t]{2}{*}{ fund year in which investment was made (1 to 10 ) } & $-0.047^{* *}$ & $-0.038^{*}$ & -0.022 & -0.025 & $-0.032^{* *}$ & $-0.039^{* * *}$ \\
\hline & 0.020 & 0.020 & 0.019 & 0.016 & 0.014 & 0.013 \\
\hline \multicolumn{7}{|l|}{ Market conditions at time of investment } \\
\hline \multirow[t]{2}{*}{ BAA corporate bond yield (in \%) } & -0.021 & -0.007 & 0.002 & -0.010 & -0.024 & $-0.040^{* *}$ \\
\hline & 0.025 & 0.027 & 0.026 & 0.023 & 0.020 & 0.019 \\
\hline Adjusted $R^{2}$ & $12.7 \%$ & $10.2 \%$ & $7.8 \%$ & $7.5 \%$ & $7.7 \%$ & $7.0 \%$ \\
\hline No. of portfolio companies & 1,257 & 1,462 & 1,618 & 1,874 & 2,284 & 2,744 \\
\hline
\end{tabular}

